\title{
U.S. OIL DEPENDENCE 2014: IS ENERGY INDEPENDENCE IN SIGHT?
}

\author{
David L. Greene (Corresponding Author) \\ University of Tennessee \\ Howard H. Baker Jr. Center for Public Policy \\ 1640 Cumberland Avenue \\ Knoxville, Tennessee 37996-3340 \\ Tel.: +1-865-974-3839 \\ Email: dgreen32@utk.edu
}

\section{Changzheng Liu (Corresponding Author)}

Oak Ridge National Laboratory

National Transportation Research Center

2360 Cherahala Boulevard

Knoxville, TN 37932, USA

Tel.: +1-865-946-1306

Fax: + 1-865-946-1314

E-mail: liuc2@ornl.gov 


\begin{abstract}
The importance of reducing U.S. oil dependence may have changed in light of developments in the world oil market over the past two decades. Since 2005, increased domestic production and decreased oil use have cut U.S. import dependence in half. The direct costs of oil dependence to the U.S. economy are estimated under four U.S. Energy Information Administration Scenarios to 2040. The key premises of the analysis are that the primary oil market failure is the use of market power by OPEC and that U.S. economic vulnerability is a result of the quantity of oil consumed, the lack of readily available, economical substitutes and the quantity of oil imported. Monte Carlo simulations of future oil market conditions indicate that the costs of U.S. oil dependence are likely to increase in constant dollars but decrease relative to U.S. gross domestic product unless oil resources are larger than estimated by the U.S. Energy Information Administration. Reducing oil dependence therefore remains a valuable goal for U.S. energy policy and an important co-benefit of mitigating greenhouse gas emissions.
\end{abstract}

\title{
KEY WORDS:
}

petroleum dependence, OPEC cartel, world oil market, oil price shocks, oil price elasticity, energy security

\section{ACKNOWLEDGEMENTS}

The authors thank the U.S. Department of Energy for its support of the research presented in this paper. We thank Jake Ward for his guidance and encouragement. We are grateful to those who have reviewed this paper and helped us to improve it. 


\section{INTRODUCTION}

Now that the U.S. is poised to become once again the world's largest oil producer and U.S. oil imports have been cut in half over the past decade, should reducing oil dependence remain a fundamental energy policy goal for the U.S.? Since 2005, domestic production of petroleum has grown by 4.7 million barrels per day (mmbd) while consumption of petroleum products has declined by $1.7 \mathrm{mmbd}^{1}$ (Energy Information Administration (EIA), 2015a, table 3.1). As a result, U.S. net oil imports fell from a peak of $60 \%$ in 2005 (12.5 mmbd) to $27 \%$ in $2014(7.4 \mathrm{mmbd}){ }^{2}$ These developments have led some to conclude that the U.S. will become energy independent in the near future (e.g., Wood Mackenzie, 2014) and that the market power of the Organization of Petroleum Exporting Countries (OPEC) may soon be a thing of the past (e.g., Jaffe and Morse, 2013).

On the other hand, from early 2008 until the most recent oil price crash in late 2014 , the spot market price of crude oil averaged \$100 per barrel (Figure 1), twice the 2005 level without any reduction in output or loss of market share by OPEC (EIA, 2014a, table 9.1). This episode is profoundly different from the behavior of the world oil market when prices reached $\$ 100 / \mathrm{bbl}$ in 1979-80, and suggests that non-OPEC oil supply and world oil demand have become less priceelastic.

Recent developments in U.S. and world oil markets are likely to have important implications for U.S. energy policy. This paper assesses the status and outlook for U.S. oil dependence through 2040, updating previous assessments (Greene, 2010; Greene et al., 1998) by

\footnotetext{
${ }^{1}$ Based on a comparison of annual totals for 2005 to the 8 -month average for 2014 . Petroleum production includes crude oil and natural gas liquids and excludes renewable fuels and processing gains.

${ }^{2}$ News reports occasionally point to increases in U.S. oil exports. Although U.S. gross exports of petroleum have tripled since 2005, gross imports have remained much larger than gross exports. The U.S. remains a net importer of oil as it has been for more than half a century (EIA, 2014a, table 3.1).
} 
incorporating recent developments in U.S. and world oil markets. Section 2 explains the premises of the analysis, defining oil dependence and identifying the relevant market failure as the use of market power in world oil markets. The nature of the costs of oil dependence and how they are measured in an uncertain future is explained. Section 2 also summarizes recent changes in the U.S. and world petroleum markets: 1) dramatically increased production from U.S. tight (shale) oil formations, 2) OPEC's strategy of maintaining market share, 3) reduced price elasticities of world oil demand and non-OPEC oil supply, and 4) increased marginal oil production costs outside of OPEC. Finally, changes to Oak Ridge National Laboratory's (ORNL) Oil Security Metrics Model (OSMM) to reflect these developments and the choice of EIA Annual Energy Outlook (AEO) projections used to simulate future oil market conditions and to calculate future oil dependence costs are described. Results of the simulations are presented in section 3 .

The analysis is subject to substantial uncertainty. Estimates of price elasticities of supply and demand from different sources vary substantially. Estimating the marginal cost of oil production in a hypothetical competitive world oil market depends on a number of uncertain assumptions. Monte Carlo simulations drawing on a wide range of assumptions about future scenarios and parameter values attempt to represent such uncertainties but the future is likely to present unanticipated changes, as well.

\section{METHODS}

The key premise of this study is that OPEC has and will continue to use market power in the world oil market. Whether and how well OPEC wields market power has been the subject of 
economic research for decades with researchers taking different sides of the issue (e.g., Griffin, 1985; Gately, 1989; Dahl and Yucel, 1991; Mabro, 1998; Kaufmann et al., 2008; Kaufmann, 2011; O'Keefe, 2014). It is the authors' view that OPEC clearly has used market power in the past, although OPEC's strategies have changed with changing market conditions. We expect OPEC to continue to use market power in the future because it has the potential to do so, because its members derive substantial financial benefit from it, and because the intention to do so is clearly stated in Article 2 of OPEC's statute:

"The principal aim of the Organization shall be the coordination and unification of the petroleum policies of Member Countries and the determination of the best means for safeguarding their interests, individually and collectively." (OPEC, 2012)

From this premise it follows that the relevant market failure is imperfect competition and that the costs of oil dependence to the U.S. economy should be measured relative to a counterfactual competitive world oil market. This perspective is very different from that taken by Leiby (2007) and Brown and Huntington (2013), for example. Those studies estimate oil security premiums based on the premise that there are external costs caused by the vulnerability of an economy to oil supply disruptions. Because the two market failures analyzed are fundamentally different, it should not be surprising that the estimates of oil dependence costs produced in this study are very different from the estimates of the oil security premium.

Measuring the costs of oil dependence relative to a competitive market does not necessarily imply that the benefits of reducing oil dependence would exceed the costs of doing so. As Brown and Huntington (2015) note, our analysis is limited to estimating the direct economic costs of oil dependence. Determining whether or not any particular policy for reducing oil dependence (e.g., fuel economy standards) might be economically efficient requires 
a cost/benefit analysis. Our analysis is limited to measuring the size of the economic damages that might be avoided by reducing oil dependence.

It is useful to briefly review the theory of partial monopoly because it identifies the key parameters needed to simulate future oil market behavior and to estimate the direct costs of oil dependence to the U.S. economy. For simplicity a static framework is used; dynamics are considered in the appendix. The market power of a partial monopoly can be measured by the ratio of its profit maximizing price, $\mathrm{P}_{\max }$, to the marginal cost of production in a competitive market, C. In a static market, this ratio depends on three factors: (1) the cartel's market share (s), (2) the price elasticity of world oil demand $(\beta)$, and (3) the non-OPEC output response to a change in OPEC production $(\mu)$ which is a function of the price elasticity of non-OPEC oil supply (von Stackelberg, 1952; Greene, 1991, Huppmann and Holz, 2012). ${ }^{3}$ In a dynamic market the rate of growth of world oil demand is also critical, as shown in appendix B.

$$
\frac{P_{\max }}{C}=\frac{1}{1+\left[\frac{1}{\beta} s(\mu+1)\right]}
$$

The denominator must be greater than zero and less than or equal to one for market prices to be less than infinite and greater than or equal to marginal cost. ${ }^{4}$

A fact of fundamental importance to understanding the dynamics of the world oil market is that the short-run (e.g., 1-year) elasticities of oil supply and demand are approximately an order of magnitude smaller than the long-run elasticities. It takes years to discover new resources and

\footnotetext{
${ }^{3}$ The authors recognize that OPEC only approximates the theoretical definition of partial, monopolistic cartel. Nonetheless, the theory of partial monopoly is useful for defining the economic framework within which the cartel operates.

${ }^{4}$ Equivalently, the term in square brackets must be in the interval -1 to 0 .
} 
bring them to market, and it takes years to change the stocks of transportation vehicles and other petroleum using equipment. A consequence of the short-run inelasticity of oil supply and demand is that a much higher price can exist in the short run than can be sustained in the long run, given time for demand and supply to adjust.

Higher prices than would prevail in a competitive market damage the U.S. economy in three ways (Greene et al., 2013). Prices elevated by market power diminish the economy's productive potential. In the OSMM, these GDP losses are measured by the consumer and producer surplus losses in the oil market caused by a price increase. Price shocks create dislocations that temporarily reduce GDP until labor and capital can be reallocated. The OSMM measures these GDP losses using empirical estimates of the elasticity of GDP with respect to oil price shocks, based on the extensive published literature on the subject. In the OSMM the elasticity of GDP with respect to oil price shocks is scaled by the ratio of expenditures on oil to the GDP since the economy's vulnerability to oil price shocks generally increases with increased oil consumption (Huntington, 2005). Finally, monopolistic pricing of oil transfers wealth from oil importing economies to oil exporting economies. Although wealth transfer is not a deadweight economic loss, it is a loss to the U.S. economy. The transfer of wealth is estimated as the quantity of oil imported multiplied by the actual market price minus a hypothetical competitive market price. Detailed explanations of the cost estimation methods can be found in Greene et al. (2014). There are additional political and military costs and although these are not accounted for in this study that is not meant to imply that they are unimportant (see, e.g., Delucchi and Murphy, 2008). 
U.S. Oil Dependence: Is Energy Independence in Sight?

David Greene and Changzheng Liu

Energy Policy

\subsection{Recent Oil Market Developments}

This section reviews four apparent changes in U.S. and world oil markets that strongly affect the costs of U.S. oil dependence: 1) increased production of tight oil, 2) a change in OPEC's strategy, 3) reduced price elasticities of demand and non-OPEC supply and, 4) increased cost of producing the marginal barrel of oil outside of OPEC.

\subsubsection{Tight Oil}

U.S. production of tight oil $^{5}$ has increased dramatically in recent years, from just under 1 mmbd in 2010 to more than 3 mmbd in the second half of 2013 (EIA, 2014b) and 4.7 mmbd in 2014 (Lewis, 2015). The addition of shale oil resources increases the U.S. crude oil resource base by $35 \%$, while on a global scale the world's estimated 345 billion barrels of tight oil is approximately $11 \%$ of the estimated 3 trillion barrels of proved plus technically recoverable crude oil resources (EIA, 2013a). Increased U.S. production of tight oil is approximately equal to the total increase in world oil production since 2010, and contrasts with the period from 2004 to 2008 when world oil production did not increase (Kaufmann, 2011). Future production from tight formations is highly uncertain due to uncertainties about the extent of tight oil resources, their lifespans and rates of decline, and future technological improvements. How much oil can be produced from tight formations will affect future oil prices and U.S. oil dependence. In the simulations below we include a scenario of much higher worldwide production of tight oil than anticipated in the EIA's Reference case projection to illustrate the potential impact of much greater less costly availability of crude oil.

\footnotetext{
${ }^{5}$ Tight oil does not have a precise scientific definition. It describes oil produced from very low permeability formations of shale, sandstone and carbonate rocks from which oil cannot be extracted without the benefit of fracturing the rock to increase permeability (EIA, 2014b, p. IF-14). Tight oil (a.k.a. shale oil) is not the same as "oil shale." Oil shale is kerogen, a precursor to oil, and will not flow even if the rock containing it is fractured.
} 


\subsubsection{OPEC Strategy}

OPEC's strategies have varied over time according to market conditions and experience. In markets where short-run price elasticities are an order of magnitude smaller than long-run elasticities, a series of price shocks and price collapses can be a profit-maximizing strategy for a partial monopolist (Suranovic, 1994; Wirl, 1990). On the other hand, a strategy of sustainable high prices can be as well (e.g., Gately, 1995). However, because OPEC is an alliance of sovereign states with different circumstances and national interests and is not perfectly informed about future market conditions, it is reasonable to expect that its strategies have changed in the past and will change in the future. In 1979, the Iran-Iraq War caused a second major oil price shock as output from the two countries fell by 3.7 mmbd between 1978 and 1980. Although that supply shock was not a deliberate attempt to cause high prices, OPEC's actions from 1980 to 1985 cannot be interpreted in any other way. From 1980 to 1985 , OPEC members cut production by a combined $10 \mathrm{mmbd}$ despite the record high oil prices (Figure 2). Saudi Arabia alone cut output from 10.3 billion barrels of oil in 1980 to 3.6 billion barrels in 1985 (BP, 2014). It was necessary for OPEC to cut production to keep oil prices elevated because over time the market response steadily increased. OPEC has two fundamental strategies for influencing world oil prices: (1) managing production from existing capacity, and (2) restricting the growth of new capacity. In general, it has been more successful at the latter strategy than the former (Smith, 2009, p. 152) but the $1980-1985$ period is a prominent exception.

OPEC's actions from 2008 to 2014 stand in sharp contrast to their production decisions from 1979-1985. Both periods began with prices exceeding \$100/bbl. But from 2008 to 2014, OPEC did not reduce production. In 2013 OPEC production was $36.8 \mathrm{mmbd}$ versus $36.3 \mathrm{mmbd}$ in 2008. OPEC output dipped to $34.0 \mathrm{mmbd}$ in 2009 in the midst of the worldwide recession but 
rebounded to $35 \mathrm{mmbd}$ in 2010, $35.9 \mathrm{mmbd}$ in 2011 and $37.4 \mathrm{mmbd}$ in 2012 (BP, 2014). The first ten months of 2014 averaged $36.4 \mathrm{mmbd}$ versus $36.6 \mathrm{mmbd}$ for the same period in 2013 (EIA, 2015). Despite this, from January 2008 to December 2014 the Brent spot price for crude oil averaged $\$ 100 / \mathrm{bbl}$. What happened to the market responses that forced OPEC to drastically cut production from 1980-1985?

Undoubtedly, unplanned outages of oil production due to civil wars and terrorist actions constrained OPEC's ability to increase its output. Sieminski (2014) estimates that unplanned crude oil production outages ranged from $1.5 \mathrm{mmbd}$ in 2010 to $3 \mathrm{mmbd}$ in 2014 and that almost all of the lost output occurred within OPEC. The term "terror premium" describes the bidding up of current and future oil prices due to the threat of further losses of supply due to turmoil in oil producing regions. In 2005 the terror premium was estimated by market analysts at between \$5 and \$20 per barrel (STRATFOR, 2005). But a terror premium cannot explain why the responses of world oil demand and non-OPEC supply were so much smaller from 2008 to 2014 than they were during 1980 to 1985.

The 2008-2014 episode implies two important changes in the world oil market. First, OPEC appears to have adopted a strategy of maintaining its market share rather than the price of oil. OPEC reduced production only slightly in 2009 when oil prices collapsed and apparently will not cut production as a result of the second oil price collapse in late 2014. Following the 2009 price collapse, OPEC waited two years for oil prices to recover to $\$ 100 / \mathrm{bbl}$ and they appear to be following the same strategy today (Figure 1). Allowing prices to collapse and rise is one of the strategies identified as potentially profit maximizing by Wirl (1990) and Suranovic (1994).

Second, the fact that prices averaged $\$ 100 / \mathrm{bbl}$ over a six-year period without OPEC cutting production or losing market share is prima facie evidence for decreased price elasticites 
of demand and non-OPEC supply. From 1979 to 1985, world oil consumption decreased by $7.2 \%$ while non-OPEC supply increased by $15.4 \%$. Over that period, the price of oil averaged $\$ 82 / \mathrm{bbl}$ (BP, 2014). From 2008 to 2013, on the other hand, world demand increased by $6.0 \%$ and non-OPEC supply increased by only 7.0\% (BP, 2014), while the Brent spot price averaged $\$ 100 / \mathrm{bbl}$. It appears that OPEC could wait out the price collapse of 2009 because two of the three key determinants of its market power, the price elasticities of world oil demand and nonOPEC supply had changed dramatically in its favor over the preceding two decades.

The flipside of highly inelastic supply and demand is prices that are highly sensitive to quantities (Difiglio, 2014). A (constant) price elasticity of demand of -0.05 implies that a $4 \%$ price increase would reduce demand by only $0.2 \%$ but a $4 \%$ increase in quantity supplied would cut the price of oil in half, all else equal. ${ }^{6}$ Because of this the surge in U.S. tight oil production plus gradually declining OECD oil consumption and a slowing of the growth of Chinese oil demand were apparently sufficient to cause oil prices to collapse in late 2014. As in 2009, OPEC appears to be willing to wait for prices to recover.

\subsubsection{Price Elasticities of Oil Demand and Supply}

It has long been recognized that world oil supply and demand are inelastic in the long run and even less responsive to price in the short run. A review of demand elasticities by Greene et al. (1998) found mean and median values of -0.07 and -0.06 for the short run (one year) and -

\footnotetext{
${ }^{6}$ A constant elasticity is assumed for convenience of calculation. Given the short-run inelasticity of oil demand and supply, the price elasticity of net demand for OPEC oil must increase as price increases or the von Stackelberg equation will be undefined.
} 
0.65 and -0.54 for the long-run, respectively, implying a median adjustment rate of $0.89 .^{7}$ Atkins and Jazayeri's (2004) review of oil demand elasticity estimates concluded that the central tendency of short-run elasticity estimates was -0.05 , while long-run elasticity estimates had a mean of -0.36 and a median of -0.32 , implying an annual adjustment rate of about 0.85 . Similar results were found by Cooper (2003) in a review of estimates from 23 countries. Gately and Huntington (2002) found that demand elasticity estimates were smaller in non-OECD (Organisation for Economic Cooperation and Development) countries than OECD countries: 0.03 in the short run and -0.16 to -0.27 in the long run. This is undoubtedly due in part to price controls in countries like China, policies that may change in the future. The U.S. EIA's ShortTerm Energy Model has a price elasticity of U.S. crude oil demand of -0.037 for a 2-year time horizon (Costello, 2006).

There are fewer estimates of the price elasticity of oil supply but there is a clear consensus that supply is similarly price-inelastic and that adjustment to price changes is slow. Huntington (1991) reviewed non-OPEC oil supply elasticities and found a mean short-run price elasticity of +0.03 for total non-OPEC supply and +0.05 for the U.S. Huntington's analysis of six energy models found an average U.S. price elasticity of +0.068 for the short run and 0.462 for the long run, implying an average adjustment rate of 0.85 . In an analysis of OPEC's incentives to expand production capacity, Gately (2004) assumed world oil supply elasticities ranging from +0.03 to +0.05 in the short run and 0.15 to 0.58 in the long run, implying

\footnotetext{
${ }^{7}$ Most econometric models of world oil demand and supply employ some form of dynamic adjustment model. The term "adjustment rate" as used in this paper refers to the coefficient of the dependent variable, lagged one year, or its equivalent. An adjustment rate of 0.85 implies that $1-0.85=0.15$, or $15 \%$ of the ultimate adjustment to a price change occurs in the year of the price change. The long-run effect will be $1 /(1-0.85)=6.667$ times the shortrun effect.
} 
adjustment rates between 0.8 and 0.91 . The International Energy Module of the National Energy Modeling System employs a constant (long-run) oil supply elasticity of +0.25 (EIA, 2013b).

Recent studies indicate that the price elasticities of both oil supply and demand have decreased sharply over the past decade or two. Difiglio (2014) reviewed estimates of the shortrun price elasticity of gasoline demand as indicators of the price elasticity of oil demand and concluded: "Studies that analyzed more recent data show a dramatic decrease of the short-run elasticity of gasoline." Long-run and short-run demand and supply elasticities for the world were estimated by Krichene (2005). The short-run (1 year) price elasticity of crude oil demand was estimated to be -0.05 for the entire period of $1918-2004$ but -0.003 for the more recent 1974 2004 period. Long-run elasticities were estimated to be -0.27 for the period $1918-2004$ and -0.26 for 1974-2004. The long-run price elasticity of supply was estimated to be +0.25 for the same period. Based on data from 1990-2009, the International Monetary Fund (2011) reported shortrun price elasticities of oil demand of -0.025 for OECD countries and -0.007 for non-OECD countries. The respective long-run elasticities were also much lower than historical estimates: 0.093 for OECD and -0.035 for non-OECD countries. Using asymmetric price response models, Dargay and Gately (2010) estimated price elasticities of oil demand for six world regions. They concluded that global price elasticity had decreased due to a shift in oil demand towards less price-responsive regions and less price responsive petroleum products. The response to oil price increases in OECD countries during the 1989-2008 period was only one-fourth as large as during the period from 1971 to 1989 . A trend of strongly decreasing price elasticities after the first two oil price shocks was also found by Baumeister and Peersman (2013) who estimated a timevarying vector autoregressive model for the period 1974-2010. They found that short-run oil 
demand elasticities after 1990 averaged one-fifth of values seen in the 1970s and early 1980 s.

Oil supply elasticities since the late 1980s averaged one third of their prior values. ${ }^{8}$

Elasticity estimates based on post-2000 data vary widely and are not nearly as numerous as earlier estimates. However, taken together with the fact that the price of oil averaged $\$ 100$ from 2008-2014 without the necessity for OPEC to reduce its oil production, they provide reasonable evidence of sharply decreased price responsiveness. Whether the adjustment rates that determine the ratio of short- and long-run elasticities have changed is less clear. The newer elasticity estimates imply adjustment rates between 0.7 and 0.99 , which is broadly consistent with the central tendency of historical estimates (about 0.85 ).

A less price-responsive world oil market is bad news for economies that consume and import large quantities of petroleum because it magnifies the market power of the cartel and increases the volatility of prices. The less responsive demand and supply are to price, the smaller the reduction in output required to sustain high oil prices. As shown in appendix B of this paper, when demand is growing it may not be necessary to cut production in order to keep prices above the long-run profit maximizing level.

\subsubsection{The Counterfactual Competitive World Oil Price}

Estimating the costs of oil market power requires comparison to a counterfactual price of oil in a competitive world oil market. If the price elasticity of non-OPEC oil supply decreased because remaining non-OPEC oil resources are more difficult and more costly to produce, the price of oil in a competitive market would likely increase even if OPEC members acted as

\footnotetext{
${ }^{8}$ The short-run elasticities estimated by Baumeister and Peersman (2013) are generally higher than those of the other studies cited both before and after the transition to less elastic demand.
} 
competitive producers. Growth in world oil demand (12 million barrels per day from 2000 to 2012) would also tend to raise the competitive market price. However, these effects could be offset by advances in oil production technology (e.g., Gorelick, 2010). Unfortunately, there is no perfect method for estimating what the price of oil would be if all world oil producers behaved as competitive suppliers (price takers). Greene and Leiby (2006) recommend considering estimates from three different sources: (1) price estimates produced by world energy market simulations, (2) the lowest oil prices observed in recent decades, and (3) calculations based on calculated long-run oil supply and demand curves.

Greene and Leiby (2006) reviewed estimates of competitive market prices based on world energy model simulations and found a range from $\$ 9.26$ to 16.20 (2013 \$). The studies are out of date, however, having been published between 1987 and 1997. Huppman and Holz (2012) simulated world oil prices in a competitive market and produced estimates ranging from $\$ 40 / \mathrm{bbl}$ to $\$ 60 / \mathrm{bbl}$ over the period 2005 to $2009 .{ }^{9}$ These prices are consistent with important changes in non-OPEC supply or demand, or both.

The lowest oil prices in the past 50 years occurred in $1970(\$ 10.79)$ and $1998(\$ 18.17)$, both in 2013 dollars. For a period of 18 years between 1986 and 2003, the annual average price of oil stayed with the range of $\$ 18-\$ 42 /$ barrel (BP, 2014). Since this followed the end of OPEC's efforts to sustain high oil prices following the price shock of 1979-80, it may reflect nearly competitive world oil market conditions.

\footnotetext{
${ }^{9}$ Huppman and Holz (2012) state that their petroleum supply curves were derived from Aguilera et al.'s (2009) production cost estimates which rely on U.S. Geological Survey (USGS) estimates of current and future oil resources.
} 
A third approach is to calculate a competitive market price using constructed long-run world oil supply and demand functions. ${ }^{10}$ International Energy Agency (IEA) (2013, Figure 13.17) and Global Energy Assessment (GEA) (2012, Figure 7.8) curves showing the cost of supplying petroleum as a function of technically recoverable resources were converted to annual supply curves by applying an average ratio of annual production to technically recoverable resources. For oil producers outside of the Middle East, the ratio of annual production to reserves plus remaining technically recoverable resources is $1.93 \%$. The corresponding ratio for the Middle East is $1.04 \%$. Applying the rest-of-world rate of $1.93 \%$ to all producers almost doubles production from the Middle East but leaves the rest of the world at the same average ratio.

A high-cost, long-run world oil supply curve can be constructed using supply cost estimates from the IEA (2013, Figure 13.17) and averaging resource estimates for only conventional oil from the USGS and Germany's Bundesanstalt für Geowissenschaften und Rohstoffe (BGR) reported in GEA (2012, table 7.6) and shown in Appendix Table A-1. The simple average of the USGS and BGR estimates is used in the calculations. According to the 2013 IEA supply estimates conventional oil can be produced in the Middle East and North Africa for between $\$ 15$ and $\$ 25$ per barrel and in the rest of the world for from $\$ 15$ to $\$ 70$ per barrel. Assuming that supply costs increase linearly with production volume in each region, 55 mmbd is available at between $\$ 15$ and $\$ 25$ per barrel and the remaining production, $45 \mathrm{mmbd}$, is available at between $\$ 25$ and $\$ 70$ per barrel. Fitting a constant elasticity function to these points yields the grey curve shown in Figure 3 as "IEA 2013."

\footnotetext{
${ }^{10}$ Prices in the remainder of this paper are in constant 2012 dollars to be consistent with the 2014 Annual Energy Outlook projections used to evaluate future costs.
} 
$\mathrm{Q}=24.737(\mathrm{P}-15.000)^{0.351}$

An alternative supply curve was derived from GEA (2012) Figure 7.8, which includes both conventional and unconventional oil reserves plus resources. An annual production rate of $1.93 \%$ of reserves plus resources was assumed. Three points on the derived curve $(\$ 17,0 ; \$ 40$, 93; \$109, 232) yield the following long-run supply function.

$\mathrm{Q}=11.720(\mathrm{P}-17.135)^{0.661}$

The lowest cost supply curve was derived from an earlier version of the IEA global oil cost graph (IEA, 2005) using the same method applied to IEA's 2013 graph. Oil costs in 2005 dollars were converted to 2012 dollars using the implicit price deflator of U.S. GDP.

$\mathrm{Q}=6.455(\mathrm{P}-5.855)^{0.876}$

A world demand curve was defined by a long-run price elasticity of -0.4 and the 2012 world oil price and quantity consumed from the BP Statistical Review (2014): \$113/bbl and 86.3 mmbd. Prior to 2012 , world oil prices had been in the vicinity of $\$ 100 /$ bbl for almost a decade and quantities had remained near $85 \mathrm{mmbd}$. Thus, assuming that the 2014 (price, quantity) point approximates a long-run equilibrium seems plausible. Solving for the prices that equate supply and demand for the three oil supply curves yields hypothetical competitive world oil prices of 
$\$ 37.70, \$ 50.55$ and $\$ 72.95$ per barrel (2012 dollars). The range of prices is very close to the more recent simulation by Huppman and Holz (2012).

The combination of reduced price responsiveness and increased marginal costs of production outside of OPEC imply a new world oil market regime in which prices are likely to continue to be higher and more volatile than those of the nearly two decades from 1986 to 2004. The extent to which these negative developments will be overcome by the favorable changes in U.S. petroleum supply and demand is the question we attempt to answer below.

\subsection{The Oil Security Metrics Model}

The OSMM was developed by ORNL to prospectively estimate the costs of U.S. oil dependence as well as the benefits of technological progress and policies that reduced oil dependence (Greene and Leiby, 2006). The model uses Monte Carlo simulation to represent an uncertain future. Details are available in Greene et al. (2014). Two previous analyses using the OSMM are described in Greene (2010) and Greene et al., (2013). The core of the model is comprised of linear, lagged adjustment equations for U.S. and rest of world oil supply and demand. At the start of an iteration the model samples the value of key parameters (e.g., price elasticities) from specified probability distributions and self-calibrates to a U.S. EIA AEO projection. To reflect the inherent uncertainty of future oil prices (Hamilton, 2009) the OSMM simulates supply shocks by means of a stochastic model calibrated to the frequency and size of historical deviations of OPEC production from AEO projections. ${ }^{11}$ In the event of a supply shock, the model calculates new equilibrium prices and quantities. That supply shocks induce

\footnotetext{
11 Deviations from AEO projections were used because the OSMM is calibrated to AEO projections.
} 
price shocks is well established whereas the possibility that demand shocks may also create price shocks has not been (Kolodzeij and Kaufmann, 2014; Kaufmann, 2011). The number and quantity of supply disruptions has increased with intensifying turmoil in the Middle East. Since 2011, supply outages have averaged 3 mmbd (Difiglio, 2014).

For every iteration the OSMM calculates three measures of the cost of oil dependence in comparison to a hypothetical competitive world oil price: (1) transfer of wealth from the U.S. to oil exporting economies, (2) loss of GDP due to higher than competitive market prices, and (3) temporary losses of GDP due to sudden price shocks. Each iteration's results are saved, creating distributions of future oil dependence costs for each year of the forecast.

The original OSMM shock simulator did not include an OPEC market share recovery mechanism. The OSMM's price shock simulator was recently improved to allow OPEC to recover market share after a price shock. Historical oil supply data shows that OPEC tends to gradually increase production after a major supply shock in order to restore its market share. For example, in 1985 OPEC's market share had fallen to $28 \%$ after six years of cutting oil production to sustain high oil prices. After 1985, OPEC gradually increased its production level so that by 1996 its market share was restored to $40 \%$. Following each price shock the newly added recovery algorithm increases OPEC's oil production so that it asymptotically approaches the market share of the un-shocked AEO production path. The rate at which production is increased was calibrated to the historical data. A set of four price paths generated by the price shock model are shown for illustrative purposes in Figure 4.

The price sensitivities of both oil supply and demand in the OSMM were decreased to be more consistent with recent evidence. The average price elasticity of U.S. demand used to calculate the average price slope for the period of 1970-2000 was assumed to be -0.079 . 
The price slope is assumed to decrease linearly over time after 2000 such that it is $1 / 2$ as large in 2010 and 1/5 as large in 2040. The same procedure was used to adjust the price slopes for U.S. demand and supply, and for the rest of world oil demand and supply. The resulting long-run price elasticities are more consistent with recent estimates, as shown in the Figure 5. Because the OSMM represents oil supply and demand with linear, lagged-adjustment equations, price elasticities change over time as prices and quantities change

\subsection{Oil Market Scenarios}

Four alternative projections of the EIA's 2014 AEO were used to reflect uncertainties in future oil market fundamentals: (1) Reference Case, (2) High Oil Price (HOP) Case, (3) Low Oil Price (LOP) Case, and (4) High Oil and Gas Resource (HOGR) Case. In the simulations below, we assign probabilities to each of the three price cases (LOP, Reference and HOP) and run a joint simulation including all three. Because prices have fallen precipitously since the 2014 AEO was issued, we also run a separate simulation based on only the LOP Case. Finally, because U.S. oil production from tight formations has increased rapidly in the past three years we run a separate simulation based on only the HOGR Case.

The three price cases reflect a range of assumptions about economic growth and conditions for oil supply. The Reference Case assumes that U.S. GDP grows at an average annual rate of $2.4 \%$ per year. The LOP Case assumed slower economic growth than the Reference Case and a higher level of oil supply. The HOP Case assumes more rapid economic growth and more restricted oil supply. Details can be found in EIA (2014b). In the Reference Case, oil prices are assumed to increase from $\$ 94 / \mathrm{bbl}$ in 2012 to $\$ 139 / \mathrm{bbl}$ by 2040 . Net imports of petroleum decrease from $7.5 \mathrm{mmbd}$ in 2012 to $5.0 \mathrm{mmbd}$ in 2025 and then increase to 5.9 mmbd by 2040. Total U.S. petroleum use (including liquids from natural gas) is relatively flat, 
starting at $17.5 \mathrm{mmbd}$ in 2012 and finishing at $17.3 \mathrm{mmbd}$ in 2040. In the High Oil Price Case, the price of oil increases steadily to $\$ 202 / \mathrm{bbl}$ in 2040 , while in the Low Oil Price Case oil prices decline to $\$ 67 / \mathrm{bbl}$ by 2020 and finish at $\$ 73 / \mathrm{bbl}$ in 2040 . All of the cases include continued vehicle fuel economy improvements required by existing U.S. standards.

The High Oil and Gas Resource (HOGR) Case is included to assess the potential impacts of greatly increased domestic oil supply on future U.S. oil dependence (EIA, 2014b, p. IF-10). In the 2014 AEO HOGR Case U.S. production of tight oil increases to $8.5 \mathrm{mmbd}$ in 2035 compared to $3.7 \mathrm{mmbd}$ in the Reference Case (Figure 6). Estimated ultimate recovery rates are 50\% higher than the Reference Case, there is increased Alaskan oil production and production from U.S. oil shale (kerogen in distinction to tight oil) resources (EIA, 2014b, p. IF-2). Total U.S. crude oil production peaks at $13.3 \mathrm{mmbd}$ in 2036 versus $7.8 \mathrm{mmbd}$ in the Reference Case. In the Reference Case, U.S. net imports of crude oil and petroleum products as a percent of consumption decrease from $41 \%$ in 2012 to $25 \%$ in 2016 and rise gradually to $32 \%$ in 2040 . In the HOGR Case, imports decrease to $15 \%$ in 2020 and fall to zero just before 2040 (EIA, 2014b, p. ES-2). Net petroleum imports (excluding natural gas liquids) in 2040 are $9.1 \mathrm{mmbd}$ in the Low Oil Price Case, $5.6 \mathrm{mmbd}$ in the Reference Case, $3.6 \mathrm{mmbd}$ in the High Oil Price Case and essentially zero $(-0.2 \mathrm{mmbd})$ in the HOGR Case. In the HOGR Case, the price of oil declines slightly to $\$ 90 / \mathrm{bbl}$ in 2020 and then increases gradually to $\$ 123 / \mathrm{bbl}$ by 2040 .

The HOGR Case is especially relevant because the EIA's 2015 Annual Energy Outlook Reference Case projections, issued after this study was completed, assume increased U.S. oil production relative to the 2014 Reference Case. In the 2015 AEO Reference Case, U.S. crude oil production in 2020 is projected to be midway between the 2014 Reference Case projection and the 2014 HOGR Case projection. In 2040 the 2015 Reference Case U.S. crude oil production is 
projected to be $9.4 \mathrm{mmbd}$, compared to 7.5 in the 2014 Reference Case and 13.2 in the HOGR Case.

The AEO 2014 side cases did not include a comparable projection of greatly reduced U.S. petroleum demand. However, other studies estimated the benefits of dramatically reducing U.S. petroleum consumption by efficiency improvements and substitution of alternative sources of energy (e.g., National Research Council (NRC), 2013; McCollum and Yang, 2009).

In the simulations that follow, we round the counterfactual competitive market price estimates to $\$ 40$ for the 2014 AEO Low Oil Price Case, $\$ 50$ for the Reference Case, and $\$ 70$ for the High Oil Price Case. The $\$ 50 / \mathrm{bbl}$ competitive world oil price assumption was also used in the High Oil and Gas Resource Case. In each case, the hypothetical competitive price is assumed to increase over time at the same annual rate as the respective case's projected oil price.

Uncertainty enters the simulations in three ways. Eight parameters were specified as probability distributions rather than scalar values (Table 1). The OSMM generates random price paths as a consequence of the supply shock model described above. Finally, the OSMM randomly selects among AEO Oil Price Cases.

Ten thousand simulations were run for each of three scenarios. The first scenario includes all three Oil Price Cases, with the Reference Case assigned a probability of 0.4 , and the other two given equal probabilities of 0.3 . Next a set of 10,000 simulations based solely on the Low Oil Price Case were run to reflect the possibility that oil prices will not return to the vicinity of $\$ 100 / \mathrm{bbl}$ except possibly during future oil price shocks. Oil prices in the Low Oil Price Case are slightly higher than the price of oil at the time of writing (spot market prices were $\$ 59 / \mathrm{bbl}$ for WTI and $\$ 63 / \mathrm{bbl}$ for Brent on 5/11/2015). However, the LOPC projected 2016 price of $\$ 64 / \mathrm{bbl}$ 
is very close to the EIA's March 2015 Short Term Energy Outlook projection for 2016 of \$69/bbl (EIA, 2015b).

\section{RESULTS}

The simulation that includes the three 2014 AEO Oil Price Cases (but not the HOGR Case) indicates that oil dependence costs relative to GDP are likely to be lower in the future (Figure 7). The mean of the simulations is shown in the figures below as a solid black line. Eighty percent of the simulation results lie within the area shaded dark gray and $90 \%$ within the light gray area. The distribution of historical estimates reflects uncertainty about parameter values and the hypothetical competitive market price. The distribution of future estimates is also affected by uncertainty about oil market conditions. While oil costs as a percentage of GDP are estimated to be smaller than in the past, U.S. GDP nearly doubles over the forecast period. In the Reference Case, U.S. GDP increases from $\$ 13.6$ trillion in 2012 to $\$ 26.7$ trillion in 2040. Oil dependence costs are less than 2\% of GDP in $95 \%$ of the simulation runs until 2040 and the mean is below $1 \%$ of GDP from 2020 through 2040. The combination of increased domestic oil production and nearly constant oil consumption reduces the relative magnitude of oil dependence costs in spite of the projections of substantially higher oil prices and a less price-responsive world oil market.

In constant dollars, however, total oil dependence costs trend upwards (Figure 8). From 2020 to 2040, the mean annual cost increases from about $\$ 150$ billion to about $\$ 250$ billion. There is some chance that future oil dependence costs could be greater than the historical highs in 1981 and 2008. The $95^{\text {th }}$ percentile increases from about $\$ 300$ billion to $\$ 600$ billion per year. 
In terms of constant dollars, the economic value of reducing petroleum dependence remains high through 2040.

Even though the future counterfactual competitive market prices are higher than historical estimates, transfer of wealth is still likely to be the largest component of U.S. oil dependence costs in the future as long as the U.S. remains an importer of large quantities of petroleum (Figure 9). The mean value trends upward from about $\$ 60$ billion per year around 2020 to $\$ 120$ billion in 2040 . Future uncertainty is largely determined by the AEO oil price projections and their associated levels of oil imports. The pattern of wealth transfer losses is similar to the pattern of total losses but more closely follows changes in oil prices.

GDP losses are smaller and follow a smoother trend over time (Figure 10). The OSMM assumes that U.S. demand and supply functions adjust slowly to the higher oil prices. This implies that the triangular areas under the demand and supply curves that measure surplus losses increase gradually. The decreased elasticity of oil supply and demand makes the curves steeper, reducing surplus losses. Still, as long as the United States remains a major consumer of petroleum, its economy will be subject to losses from higher than competitive market prices and to price shocks.

Disruption costs are the most uncertain component of future oil dependence costs. The bounds for $90 \%$ of the simulations ranges from $\$ 0$ to over $\$ 300$ billion per year. Disruption costs are bounded by zero. There are no economic gains from disruptions and when there are no price shocks costs are zero. On the other hand, sudden price decreases as well as increases can cause disruption costs. The price collapse of 1986, for example, is clearly visible in Figure 11. Estimated future disruption costs show the greatest variance because the stochastic generation of supply shocks produces many instances of zero or near zero disruption costs. 
Results for the Low Oil Price Case (LOPC) alone are similar to those that include all three Oil Price Cases, except that oil dependence costs are slightly higher in the LOPC than in the simulations that includes the higher oil price cases (Figure 12). This result may seem counterintuitive and deserves further explanation. Several factors mitigate against reduced oil dependence costs in the LOPC. First, U.S. oil imports are much higher, which increases the potential for transfer of wealth (calculated as imports multiplied by actual oil price minus competitive oil price). In 2020 the import share of total U.S. petroleum products supplied is $17.3 \%$ in the HOPC and $30.2 \%$ in the LOPC. The gap increases such that by 2040 the import share in the LOPC $(45.6 \%)$ is more than twice that in the HOPC $(21.1 \%)$ and considerably higher than the Reference Case (32.2\%). Second, the counterfactual competitive market price in the LOPC is assumed to have a mean value of $\$ 40 / \mathrm{bbl}$, while the mean is assumed to be $\$ 70 / \mathrm{bbl}$ in the more oil-scarce world of the HOPC and \$50/bbl in the Reference Case. Increased, less costly world oil supply is a fundamental premise of the LOPC, from which it follows that the price of oil in a competitive market would also be lower. Third, because in the OSMM the price elasticities of supply and demand increase with increasing price, supply and demand are least sensitive to price in the LOPC, creating a potential for larger price shocks. The OSMM produces futures with one or more price shocks far more often than not. Adding to this potential is the higher output and market share of OPEC in the LOPC. In the LOPC OPEC production steadily increases from $36.5 \mathrm{mmbd}$ and $41.8 \%$ of the market in 2012 to $60.8 \mathrm{mmbd}$ and $52.8 \%$ of the market in 2040. This compares with $51.4 \mathrm{mmbd}$ (45.5\% market share) in the Reference Case and $44.9 \mathrm{mmbd}(40.4 \%$ share) in the HOPC. In the OSMM, higher levels of OPEC production allow larger supply shocks and increased market share confers greater market power. Finally, the U.S. economy's vulnerability to the costs of oil dependence increase with increasing 
consumption and U.S. consumption grows to $20.1 \mathrm{mmbd}$ in the LOPC versus $17.5 \mathrm{mmbd}$ in the HOPC and 18.7 in the Reference Case. Of course, the results are also influenced by specific modeling assumptions (e.g., linear, lagged adjustment supply and demand functions), by the details of the AEO projections and by the assumed parameter values (see Table 1). The general inference should be that U.S. oil dependence costs are not highly sensitive to the choice of AEO oil price scenario.

In contrast, the gradual elimination of U.S. oil imports in the HOGR Case greatly reduces the estimated costs of U.S. oil dependence (Figure 13). Although wealth transfer costs disappear when oil imports reach zero, there are still GDP losses from higher than competitive market prices and from price shocks. The average annual cost falls below $\$ 100$ billion per year before 2020, however, and 95 percent of the simulations produce annual costs below $\$ 250$ billion from the present through 2040 .

As a percentage of GDP, oil dependence costs in the HOGR Case are below $1 \%$ in $95 \%$ of the simulations (Figure 14). This satisfies Greene's (2010) proposed definition of energy independence, which is oil dependence costs that are less than $1 \%$ of GDP with $95 \%$ probability. Greene proposed this definition based on the fact that during the decade from 1990 to 1999 concern about U.S. oil dependence was minimal and oil costs were consistently less than $1 \%$ of U.S. GDP. However, there is no generally accepted quantitative definition of energy independence.

\section{DISCUSSION}

Since 2000, world oil supply and demand appear to have become less sensitive to oil prices. The concentration of oil demand in the transport sector and the increased share of 
developing economies that are more likely to control the prices of domestic petroleum products have been offered as explanations for the trend. A handful of recent econometric estimates support this inference. Recent assessments indicate that the marginal cost of oil production outside of OPEC has increased substantially since the 1990s, probably to between $\$ 40$ and $\$ 50 / \mathrm{bbl}$. Additional support for a fundamental change in world oil markets comes from the fact that oil prices averaged $\$ 100 /$ barrel from 2008 to 2014 without the necessity for OPEC to sacrifice market share. However, at the close of 2014 oil prices declined rapidly to $\$ 40-\$ 50 / \mathrm{bbl}$. Increased production from U.S. tight oil resources plus gradually declining demand from OECD economies and a slowing of the growth of demand from China are frequently cited as the causes. Decreased price elasticities magnify the market power of the OPEC cartel. Higher non-OPEC marginal costs also contribute to higher market prices. On the other hand, increased U.S. oil production and declining consumption reduces oil imports and the economy's vulnerability to price shocks.

Since 2005, U.S. oil imports have been cut in half. This has also halved the transfer of wealth from the U.S. economy to oil exporting economies. Continuing low oil prices in early 2015 have further benefitted the U.S. economy. Decreasing U.S. oil demand due to the market's response to higher oil prices and to fuel economy and greenhouse gas emissions standards also reduces the U.S. economy's vulnerability to possible future high prices and price shocks.

These opposing oil trends have major implications for U.S. energy policy. Reducing the costs of oil dependence has been an important justification for improving energy efficiency, developing substitutes for petroleum and increasing domestic petroleum production, as well as an important co-benefit of greenhouse gas mitigation. The extent to which oil dependence will continue to be a drag on the U.S. economy in the future will strongly influence the future 
benefits of such policies. The simulations described above indicate that unless world oil resources, and especially U.S. tight oil resources, are greater than estimated by the EIA, U.S. oil dependence will continue to cost the U.S. economy hundreds of billions of dollars per year for decades to come. Choice of AEO oil price scenario had little impact on the estimated oil dependence costs because of countervailing effects, for example, low oil prices lead to increased consumption, decreased domestic production and thus increased imports. Assuming that future price shocks are likely, future U.S. oil dependence costs do not seem to be highly sensitive to EIA's alternative oil price scenarios.

\section{CONCLUSIONS AND POLICY IMPLICATIONS}

This study has analyzed the implications of recent oil market developments for the future costs of U.S. oil dependence. ORNL's OSMM was used to estimate oil dependence costs to 2040 taking into consideration uncertainty about future oil market conditions. Simulations based on alternative oil price scenarios indicate that the direct economic costs of oil dependence are likely to decrease relative to U.S. GDP but increase in constant dollars, potentially ranging from $\$ 100$ billion to $\$ 600$ billion in any given year. Under these conditions the benefits of reducing U.S. oil dependence will continue to be substantial. Current U.S. policies call for continued improvements in new vehicle fuel economy and reductions in greenhouse gas emissions through 2025, as well as increased use of renewable fuels in transportation. Reduced oil dependence costs should continue to be an important co-benefit of such policies.

An optimistic scenario of greatly increased U.S. oil and gas production yielded much lower oil dependence costs, less than 1\% of U.S. GDP after 2020 in $95 \%$ of the simulation runs. This scenario satisfies Greene's (2010) quantitative definition of energy independence, as well as 
the condition that net oil imports become zero by 2040. It illustrates the fact that both increased domestic production and decreased domestic demand contribute to reducing the costs of U.S. oil dependence.

The estimates of future oil dependence costs presented in this paper are subject to substantial uncertainty due to uncertainties about parameter values and future oil market conditions. Although the simulations presented have attempted to quantify the uncertainty, it is highly likely that unforeseen possibilities will influence the oil market in the future. With this in mind, the simulations indicate that that unless U.S. oil resources are substantially greater than the EIA's 2014 AEO Reference Case estimates, or additional actions are taken to greatly reduce petroleum demand, U.S. oil dependence costs will continue to be a problem amounting to hundreds of billions of dollars per year through 2040. Under these circumstances, reducing oil dependence will continue to be an important direct benefit of policies to improve energy efficiency and an important co-benefit of reducing greenhouse gas emissions from the combustion of fossil petroleum. 
U.S. Oil Dependence: Is Energy Independence in Sight?

David Greene and Changzheng Liu

Energy Policy

\section{REFERENCES}

Aguilera, R.F., Eggert, R.G., Lagos, G., Tilton, J.E., 2009. "Depletion and future availability of petroleum resources," The Energy Journal, 30:1, 141-174.

Alhajji, A.F. and D. Huettner, 2000. “OPEC and world crude oil markets from 1973 to 1994: cartel, oligopoly or competitive?", The Energy Journal, vol. 21, no. 3, pp. 31-60.

Atkins, F.J., Jazayeri, S.M.T., 2004. A literature review of demand studies in world oil markets, Discussion Paper 2004-07, Department of Economics, University of Calgary, Calgary, Alberta, Canada.

Baumeister, C., Peersman, G., 2013. “The role of time-varying price elasticities in accounting for volatility changes in the crude oil market," Journal of Applied Econometrics, 28, 1087-1109.

BP, 2014. BP statistical review of world energy - 2013, Historical Data Workbook, accessed at http://www.bp.com/en/global/corporate/about-bp/energy-economics/statistical-review-ofworld-energy.html on 7/1/2014.

Brown, S.P.A. and H.G. Huntington, 2015. "Evaluating U.S. oil security and import reliance", Energy Policy, vol. 79, pp. 9-22.

Brown, S.P.A. and H.G. Huntington, 2013. "Assessing the U.S. oil security premium”, Energy Economics, vol. 38, pp. 118-127.

Cooper, J.C.B., 2003. "Price elasticity of demand for crude oil: Estimates for 23 countries," OPEC Review, March, 3-8. 
U.S. Oil Dependence: Is Energy Independence in Sight?

David Greene and Changzheng Liu

Costello, D., 2006. “Reduced form energy model from EIA's regional short-term energy model (RSTEM)," Energy Information Administration, available online at http://www.eia.gov/forecasts/steo/special/pdf/elasticities.pdf, accessed on 7/1/2014.

Dahl, C. and M. Yucel, 1991. Testing alternative hypotheses of oil producer behavior", The Energy Journal, vol. 12, no. 4, pp. 117-138.

Dargay, J.M., Gately, D., 2010. “World oil demand's shift toward faster growing and less priceresponsive products and regions." Energy Policy, 38, 6261-6277.

Delucchi, M.A., Murphy, J.J., 2008. U.S. military expenditures to protect the use of Persian Gulf oil for motor vehicles. Energy Policy, 36, 2253-2264.

Difiglio, C., 2014. "Oil, economic growth and strategic petroleum stocks”, Energy Strategy Reviews, vol. 5, pp. 48-58.

(EIA) Energy Information Administration, 2013a. Technically recoverable shale oil and shale gas resources: An assessment of 137 shale formations in 41 countries outside the United States, accessed at http://www.eia.gov/analysis/studies/worldshalegas/ on 7/7/2014.

(EIA) Energy Information Administration, 2013b. International energy module of the national energy modeling system model documentation 2013, available online and accessed on July 1, 2014 at, http://www.eia.gov/forecasts/aeo/nems/documentation/international/pdf/m071(2012).pdf

(EIA) Energy Information Administration, 2014a. Monthly energy review June 2014, DOE/EIA0035(2014/06), U.S. Department of Energy, Washington, DC, accessed on 7/7/2014 at http://www.eia.gov/totalenergy/data/monthly/ .

(EIA) Energy Information Administration, 2014b. Annual energy outlook 2014, DOE/EIA0038(2014), U.S. Department of Energy, Washington, DC. 
U.S. Oil Dependence: Is Energy Independence in Sight?

David Greene and Changzheng Liu

(EIA) Energy Information Administration, 2014c. "Spot prices, refiner acquisition cost of crude oil - composite," http://www.eia.gov/petroleum/data.cfm\#prices , accessed on October $24,2014$.

(EIA) Energy Information Administration, 2015a. "Total Oil Supply”, International Energy Statistics, accessed on March 23, 2015 at http://www.eia.gov/cfapps/ipdbproject/iedindex3.cfm?tid=50\&pid=53\&aid=1\&cid=CG9, $\&$ syid=2008\&eyid=2014\&freq=M\&unit=TBPD .

(EIA) Energy Information Administration, 2015b. "Table 1: U.S. Energy Markets Summary”, Short Term Energy Outllook, March 10, 2015, accessed on March 25, 2015 at http://www.eia.gov/forecasts/steo/tables/?tableNumber=3\# .

Gately, D., 1989. “Do oil markets work? Is OPEC dead?”, Annual Review of Energy, vol. 14, pp. 95-116.

Gately, D., 1995. “Strategies for OPEC's pricing and output decisions”, The Energy Journal, vol. 16, no. 3, pp. 1-38.

Gately, D., 2004. “OPEC's incentives for faster output growth,” The Energy Journal, 25:2, $75-96$.

Gately, D., Huntington, H.G., 2002. "The asymmetric effects of changes in price and income on energy and oil demand," The Energy Journal, 23:1, 19-56.

(GEA) Global Energy Assessment, 2012. Global energy assessment-toward a sustainable future, Cambridge University Press, Cambridge, UK, and the International Institute for Applied Systems Analysis.

Gorelick, S.M., 2010. Oil panic and the global crisis predictions and myths, Wiley-Blackwell, Oxford. 
Greene, D.L., 1991. “A note on OPEC market power and oil prices,” Energy Economics, 13:2, $123-129$.

Greene, D.L., 2010. “Measuring energy security: Can the United States achieve oil independence?” Energy Policy, 38:4, 1614-1621.

Greene, D.L., Jones, D.W., Leiby, P.N., 1998. “The outlook for U.S. oil dependence,” Energy Policy, 26:1, 55-69.

Greene, D.L., Leiby, P.N., 2006. The Oil Security Metrics Model, ORNL/TM-2006/505, Oak Ridge National Laboratory, Oak Ridge, TN, May.

Greene, D.L., Lee, R.S., Hopson, J.L., 2013. OPEC and the costs to the U.S. economy of oil dependence: 1970-2010, White Paper 1-13, Howard H. Baker, Jr. Center for Public Policy, The University of Tennessee, Knoxville, available at http://bakercenter.utk.edu/wp-content/uploads/2013/02/OilDependenceCosts2010-NewCover021413.pdf.

Greene, D.L., Liu, C.Z., Leiby, P.N., 2014. The Oil Security Metrics Model: 2014 Update, ORNL/TM-2014/628, Oak Ridge National Laboratory, Oak Ridge, Tennessee, September.

Hamilton, J.D., 2009. “Understanding crude oil prices,” The Energy Journal, 30:2, 179-206.

Huntington, H., 2005. “The Economic Consequences of Higher Crude Oil Prices”, EMF SR9, Energy Modeling Forum, Stanford University, Stanford, California, October 3.

Huntington, H.G., 1991. "Inferred demand and supply elasticities from a comparison of world oil models," EMF WP 11.5, Energy Modeling Forum, Stanford University, Stanford, California, January. 
U.S. Oil Dependence: Is Energy Independence in Sight?

David Greene and Changzheng Liu

Huppmann, D., Holz, F., 2012. “Crude oil market power - A shift in recent years," The Energy Journal, 33:4, 1-22.

(IEA) International Energy Agency, 2005. World Energy Outlook 2005, OECD, Paris.

(IEA) International Energy Agency, 2013. World Energy Outlook 2013, OECD, Paris.

(IMF) International Monetary Fund, 2011. World Economic Outlook: April 2011, Washington, DC.

Jaffe, A.M., Morse, E., 2013. “The end of OPEC,” Foreign Policy, October 16, 2013, http://www.foreignpolicy.com/articles/2013/10/16/the_end_of_opec_america_energy_oil accessed on October 24, 2014.

Kaufmann, R.K., 2011. "The role of market fundamentals and speculation in recent price changes for crude oil”, Energy Policy, vol. 39, pp. 105-115.

Kaufmann, R.K., A. Bradford, L.H. Belanger, J.P. Mclaughlin and Y. Miki, 2008. "Determinants of OPEC production: implications for OPEC behavior", Energy Economics, vol. 30, pp. 333-351.

Kolodzeij, M. and R.K. Kaufmann, 2014. “Oil demand shocks reconsidered: A cointegrated vector autoregression”, Energy Economics, vol. 41, pp. 33-40.

Krichene, N., 2005. “A simultaneous equations model for world crude oil and natural gas markets," IMF Working Paper WP/05/32, International Monetary Fund, African Department, February.

Leiby, P.N., 2007. Estimating the energy security benefits of reduced U.S. oil imports, ORNL/TM-2007/029, Oak Ridge National Laboratory, Oak Ridge, TN, July 23. 
Lewis, M., 2015. "US shale oil boom masks declining global supply", Financial Times, 2/11/2015, accessed at http://www.ft.com/intl/cms/s/0/a623e1e8-b11a-11e4-831b00144feab7de.html\#axzz3VDpWhcco on 3/23/2015.

Mabro, R., 1998. “OPEC behavior 1960-1998: A Review of the Literature”, The Journal of Economic Literature, vol. IV, no. 1, pp. 3-27.

McCollum, D., Yang, C., 2009. “Achieving deep reductions in U.S. transport greenhouse gas emissions: Scenario analysis and policy implications, Energy Policy, 37:12, 5580-5596.

(NRC) National Research Council, 2013. Transitions to alternative vehicles and fuels, National Academies Press, Washington, DC.

O'Keefe, W., 2014. “OPEC: The myth and the reality,” George C. Marshall Institute, Arlington, VA, June.

Organization of the Petroleum Exporting Countries (OPEC), 2012. Statute, accessed at http://www.opec.org/opec_web/static_files_project/media/downloads/publications/OPEC _Statute.pdf on 3/20/2015 , OPEC Secretariat, Organization of the Petroleum Exporting Countries, Vienna, Austria.

Smith, J.L., 2009. “World oil: Market or mayhem?” Journal of Economic Perspectives, 23:3, $145-164$.

Yergin, D., 1991. The Prize, Simon and Schuster, New York.

Von Stackelberg, H., 1952. The Theory of the Market Economy, Oxford University Press, New York, NY.

Wood Mackenzie, 2014. "U.S. will achieve energy independence by 2025," http://public.woodmac.com/public/media-centre/content/12525241, accessed on October 24, 2014. 
U.S. Oil Dependence: Is Energy Independence in Sight?

Energy Policy

David Greene and Changzheng Liu

\section{APPENDIX A}

World Conventional Oil Reserve and Resource (R+R) Estimates, 2009

Cumulativ

\begin{tabular}{|c|c|c|c|c|c|c|}
\hline Annual & $\mathrm{e}$ & & $R+R$ & Annual & Annual & \\
\hline uctio & Production & $R+R$ & (USGS & Production/( $R+R$ & Production/( $R+R$ & Averag \\
\hline
\end{tabular}

Region

USA

CAN

WEU

EEU

FSU

NAF

EAF

WCA

SAF

MEE

$\mathrm{CHN}$

OEA

IND

OSA

JPN

OCN

PAS

LAC

Total-

MEE n 2009

(EJ) 2009 (BGR)

(EJ)

(EJ)

(EJ)

$1246 \quad 582 \quad 659$

$200 \quad 129 \quad 57$

$329 \quad 275 \quad 671$

$\begin{array}{lll}47 & 19 & 26\end{array}$

$1017 \quad 1743 \quad 1906$

10.38

0.00

6.07

3.78

50.78

7.90

1.02

1.57

0.14

0.01

1.20

4.90

20.30

166.65

6649

1091

$\begin{array}{rrr}48 & 227 & 121 \\ 1823 & 5175 & 4621\end{array}$

$220 \quad 181 \quad 237$

$11 \quad 58$

$46 \quad 50$

$4 \quad 15$

58

13

0

$41 \quad 69 \quad 202$

$203 \quad 153$

86

$862 \quad 1093 \quad 1279$

tal

115.87

482

5741

6250
$336 \quad 573 \quad 410$

$1.53 \%$
) (USGS)

(\%)

e

(\%)

$2.58 \%$

$5.19 \%$

$3.27 \%$

$1.47 \%$

$1.59 \%$

$1.81 \%$

$0.00 \%$

$1.09 \%$

$1.67 \%$

$0.98 \%$

$4.36 \%$

$1.76 \%$

$3.14 \%$

$0.93 \%$

$1.00 \%$

$1.74 \%$

$3.20 \%$

$1.86 \%$

$1.53 \% \quad 1.53 \%$

210.53

$1.08 \% \quad 1.00 \%$

undefined $\quad 2.00 \%$

$0.59 \% \quad 0.89 \%$

$5.70 \% \quad 4.10 \%$

$1.59 \% \quad 1.71 \%$

22.92

e Market

Annual

Production

(EJ)

11.99

1.80

9.14

0.43

35.26

9.50

0.23

10.37

3.36

94.66

4.04

0.57

1.04

0.27

0.01

2.62

2.31

$2.02 \%$

$1.85 \% \quad 1.93 \%$

115.87 


\section{APPENDIX B}

\section{EFFECT OF REDUCTION IN SUPPLY BY VON STACKELBERG MONOPOLIST AND DEPENDENCE ON ELASTICITIES OF DEMAND AND SUPPLY AND MARKET DEMAND GROWTH}

Let world oil demand, $\mathrm{Q}_{\mathrm{t}}$, and non-OPEC supply, $\mathrm{q}_{\mathrm{t}}$, be represented by linear lagged adjustment functions of the price of oil, $\mathrm{P}_{\mathrm{t}}$. These are the simplest dynamic functions, and are a first order approximation to the "true" demand and supply functions. They are also the function forms used in ORNL's OSMM. Linear lagged adjustment models have the property that price elasticities increase with increasing price. This property is necessary for the market price to be defined in the case of very inelastic supply and demand and a substantial monopolist market share.

\section{Equation B-1}

$Q_{t}=A+B P_{t}+\lambda Q_{t-1}$

$q_{t}=a+b P_{t}+\gamma q_{t-1}$

Let OPEC supply be $x_{t}$. The short-run and long-run price elasticities of demand and supply are given in table B-1. 
U.S. Oil Dependence: Is Energy Independence in Sight?

David Greene and Changzheng Liu

Energy Policy

Table B-1. Short- and Long-Run Price Elasticities in Linear Lagged Adjustment Model

\begin{tabular}{lcc}
\hline & Short-run (1 period) & Long-run (infinite) \\
\hline Demand & $\mathrm{B}(\mathrm{P} / \mathrm{Q})$ & $\mathrm{B}(\mathrm{P} / \mathrm{Q}) /(1-\lambda)$ \\
Supply & $\mathrm{b}(\mathrm{P} / \mathrm{q})$ & $\mathrm{b}(\mathrm{P} / \mathrm{q}) /(1-\gamma)$ \\
\hline
\end{tabular}

Assuming a short-rum equilibrium of supply and demand at time $t$, the price of oil is given by the following equation.

Equation B-2

$P_{t}=\frac{A-a+\lambda Q_{t-1}-\gamma q_{t-1}-x_{t}}{b-B}$

The difference, $\mathrm{b}>0$ minus $\mathrm{B}<0$ (the denominator of equation $\mathrm{B}-2$ ) is a positive number which implies that the numerator must also be a positive number for $\mathrm{P}>0$. The market response to a reduction in OPEC supply of quantity $\Delta \mathrm{x}>0$ (so that OPEC's new supply amount is $\mathrm{x}-\Delta \mathrm{x}$ ) is an increase in price equal to $\Delta \mathrm{x} /(\mathrm{b}-\mathrm{B})$, all else equal. Note that the less price-sensitive demand and supply are (i.e., the smaller $(\mathrm{b}-\mathrm{B})>0$ is) the smaller the reduction in $\mathrm{x}$ required to accomplish a given increase in price.

Assume that the market is in a steady state at time $\mathrm{t}=0$. This implies that $\mathrm{Q}_{0}=\mathrm{A}+\mathrm{BP}_{0}+\lambda \mathrm{Q}_{0}$. Suppose that in period 1 , OPEC reduces the period 0 level of supply, $\mathrm{x}_{0}$, by $\Delta \mathrm{x}>0$, resulting in a change in price of $\Delta \mathrm{P}=\mathrm{P}_{1}-\mathrm{P}_{0}=\Delta \mathrm{x} /(\mathrm{b}-\mathrm{B})>0$. The assumption of a steady state at $\mathrm{t}=0$ implies $\mathrm{Q}_{1}$ 
$=\mathrm{Q}_{0}+\mathrm{B} \Delta \mathrm{P} .^{12}$ Assume that in period 2 OPEC continues to produce $\mathrm{x}_{0}-\Delta \mathrm{x}$, but non-OPEC supply and world demand will make short-run adjustments to the new higher price resulting in a new price, $\mathrm{P}_{2}$. To simplify the exposition, we assume that the adjustment rates for supply and demand are equal $(\lambda=\gamma)$. This is approximately correct, as the empirical evidence cited in the body of the paper indicates.

\section{Equation B-3}

$P_{2}=\frac{A-a+\lambda Q_{0}+\lambda B \Delta P-\gamma q_{0}-\lambda b \Delta P-\left(x_{0}-\Delta x\right)}{b-B}$

Both terms involving $\Delta \mathrm{P}$ are negative, which implies that $\mathrm{P}_{2}<\mathrm{P}_{1}$. Thus, in the year following a price increase caused by a reduction in OPEC supply, the market price will decrease, all else equal. To maintain the higher price level, so that $\mathrm{P}_{2}=\mathrm{P}_{1}=\mathrm{P}_{0}+\Delta \mathrm{P}, \mathrm{OPEC}$ must reduce its supply by $\Delta \mathrm{P} \lambda(\mathrm{b}-\mathrm{B})>0$. The result is intuitive: in a dynamically adjusting market with long-run price responses much greater than short-run responses, sustaining high prices requires the von Stackelberg monopolist to continue reducing supply until the long-run equilibrium is reached.

All else equal, the less price responsive supply and demand are (the smaller b-B > 0) the larger the price increase will be from a given reduction in OPEC supply. Conversely, a smaller reduction in OPEC supply will be required to maintain the price of oil in the face of decreasing demand.

\footnotetext{
${ }^{12} \mathrm{Q}_{1}=\mathrm{A}+\mathrm{B}\left(\mathrm{P}_{0}+\Delta \mathrm{P}\right)+\lambda \mathrm{Q}_{0}=\mathrm{A}+\mathrm{BP}_{0}+\lambda \mathrm{Q}_{0}+\mathrm{B} \Delta \mathrm{P}=\mathrm{Q}_{0}+\mathrm{B} \Delta \mathrm{P}$.
} 
But markets are constantly changing which will affect the production adjustments OPEC must make to maintain a higher oil price following a price increase. In the oil market, demand has been growing while at the same time it appears that price responsiveness has been decreasing. Assume that demand has been growing without increasing the price slope, that is, $\mathrm{A}$ is increasing while B remains the same. Since this will increase Q at the same price, price elasticity will decrease. Let the rate of growth in A per period be a constant $\delta$, so that $A_{t+1}=A_{t}+\delta$. Substituting $\delta+A$ for $\mathrm{A}$ in equation 3 , we see that in order to maintain $\mathrm{P}_{2}=\mathrm{P}_{1}$ in a growing market OPEC must reduce supply by $\Delta \mathrm{P} \lambda(\mathrm{b}-\mathrm{B})-\delta$. If $\delta<\Delta \mathrm{P} \lambda(\mathrm{b}-\mathrm{B})$, a smaller reduction in supply is required; if $\delta>\Delta \mathrm{P} \lambda(\mathrm{b}-\mathrm{B})$, OPEC could expand production while holding price constant. 
U.S. Oil Dependence: Is Energy Independence in Sight?

David Greene and Changzheng Liu

Energy Policy

\section{FIGURE CAPTIONS}

Figure 1. Monthly Spot Market Oil Prices: January 1986 to October 2014. (EIA, 2014c)

Figure 2. OPEC market share and world oil prices: 1965-2013.

Figure 3. Hypothetical competitive world oil market supply curves (Based on IEA, 26, 28 and GEA, 27).

Figure 4. Sample of price paths created by the OSMM supply shock model

Figure 5. Long run price elasticities of oil demand and supply.

Figure 6. U.S. crude oil production: History and three tight oil scenarios (EIA, 2014b, Figure IF2-1).

Figure 7. Estimated annual costs of U.S. oil dependence as a percent of GDP: AEO 2014 oil price cases.

Figure 8. Estimated annual costs of U.S. oil dependence in billions of 2012 dollars: AEO 2014 oil price cases.

Figure 9. Estimated annual wealth transfer costs of U.S. oil dependence in billions of 2012 dollars: AEO 2014 oil price cases.

Figure 10. Estimated annual GDP losses due to U.S. oil dependence in billions of 2012 dollars: AEO 2014 oil price cases.

Figure 11. Estimated annual disruption costs of U.S. oil dependence in billions of 2012 dollars: AEO 2014 oil price cases.

Figure 12. Estimated annual costs of U.S. oil dependence in billions of 2012 dollars: AEO 2014 low oil price case.

Figure 13. Estimated annual costs of U.S. oil dependence in billions of 2012 dollars: AEO 2014 high oil resource case. 
U.S. Oil Dependence: Is Energy Independence in Sight?

David Greene and Changzheng Liu

Figure 14. Estimated annual costs of U.S. oil dependence as a percent of GDP: high oil resource case. 
U.S. Oil Dependence: Is Energy Independence in Sight?

Energy Policy

David Greene and Changzheng Liu

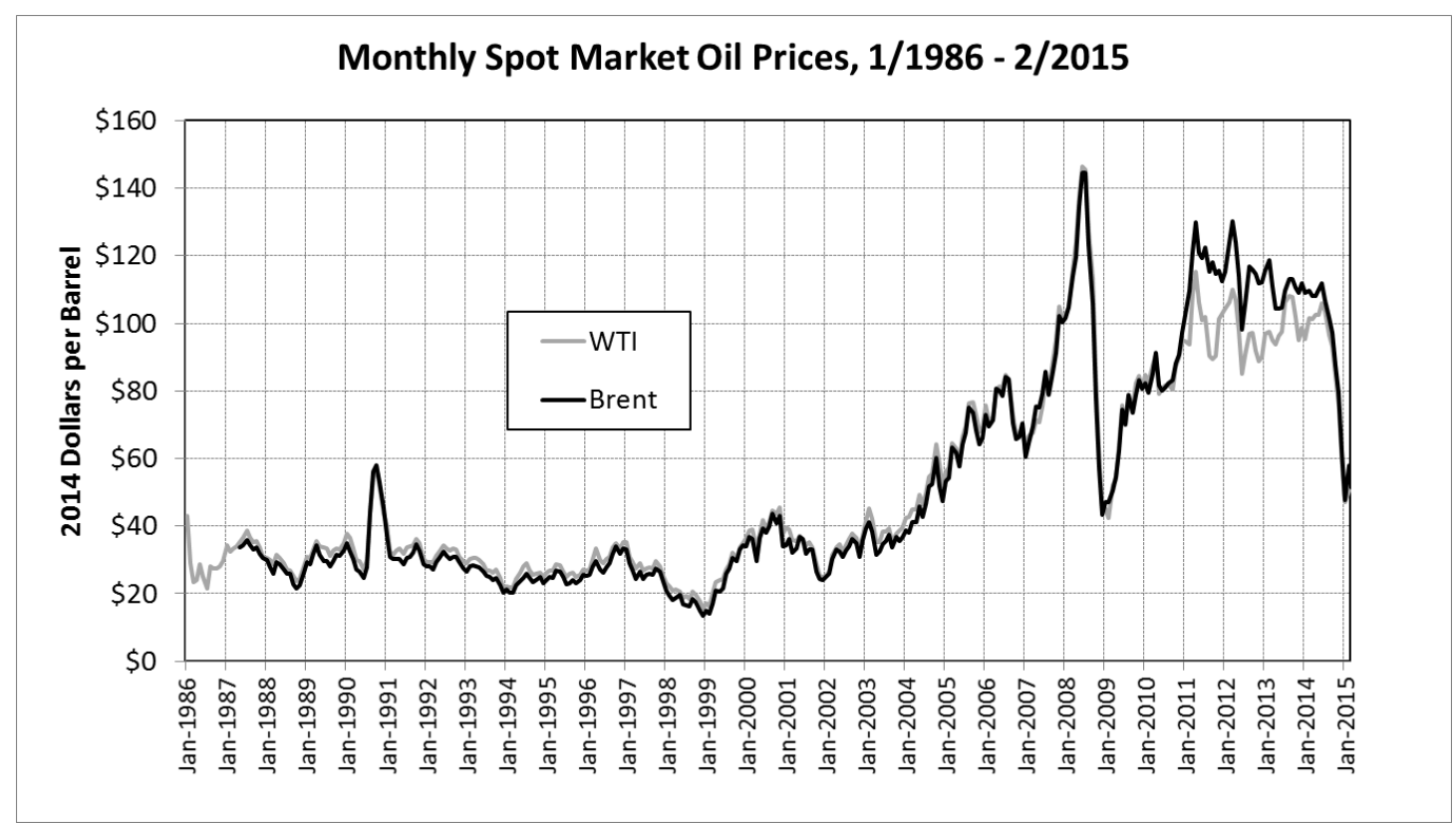


OPEC Market Share and World Oil Prices: 1965-2013

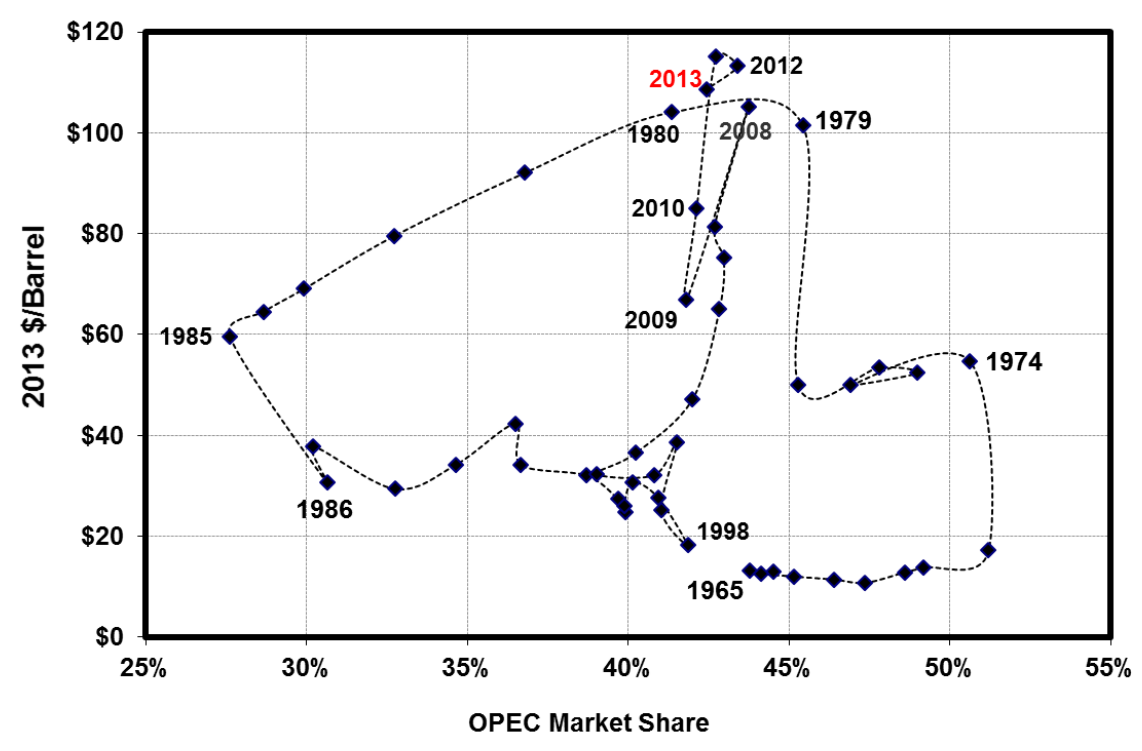

Source: BP Statistical Review of World Energy 2014. "Oil Production - barrels" and "Oil - crude oil prices since 1861". 


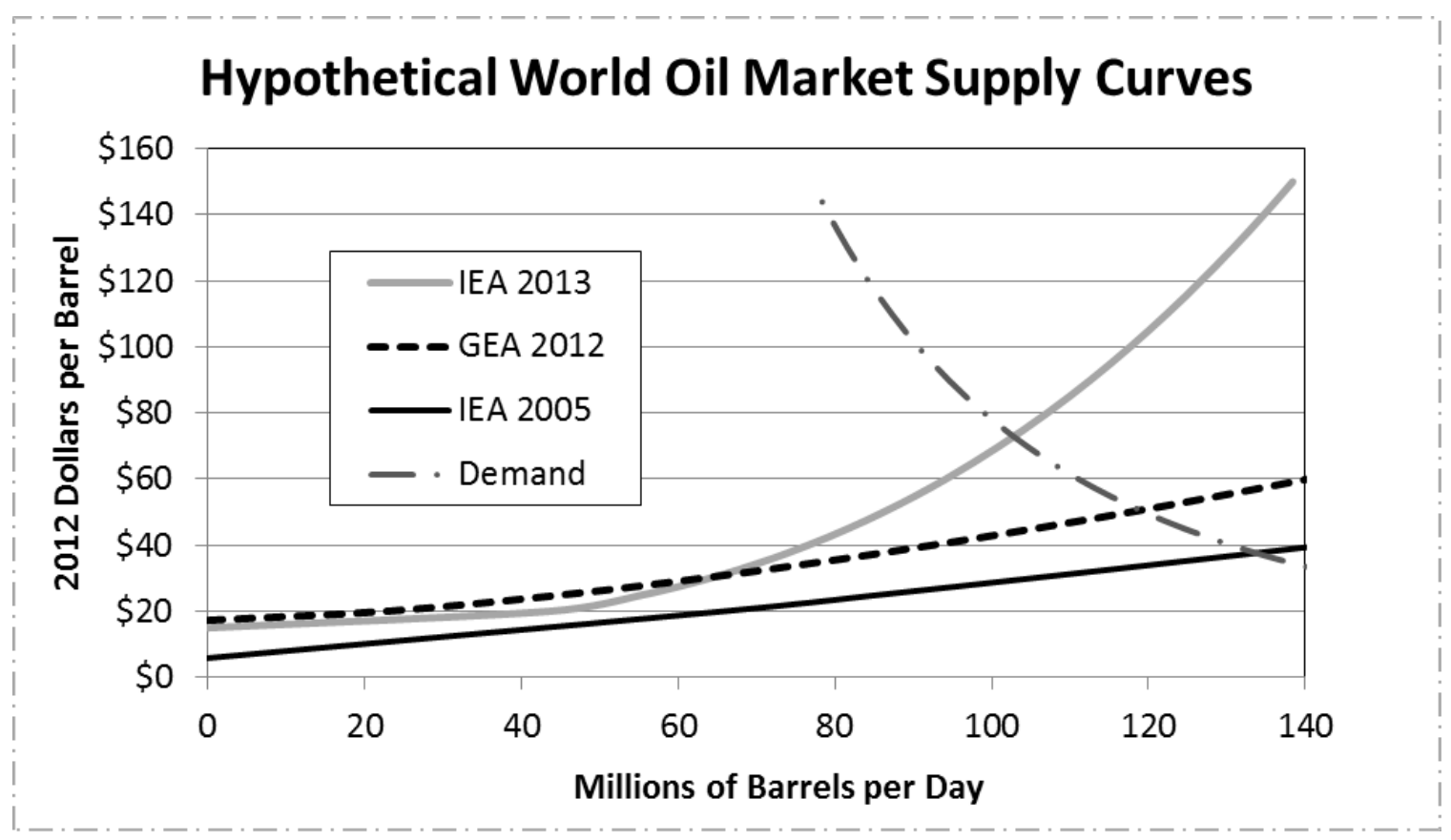


U.S. Oil Dependence: Is Energy Independence in Sight?

Energy Policy

David Greene and Changzheng Liu

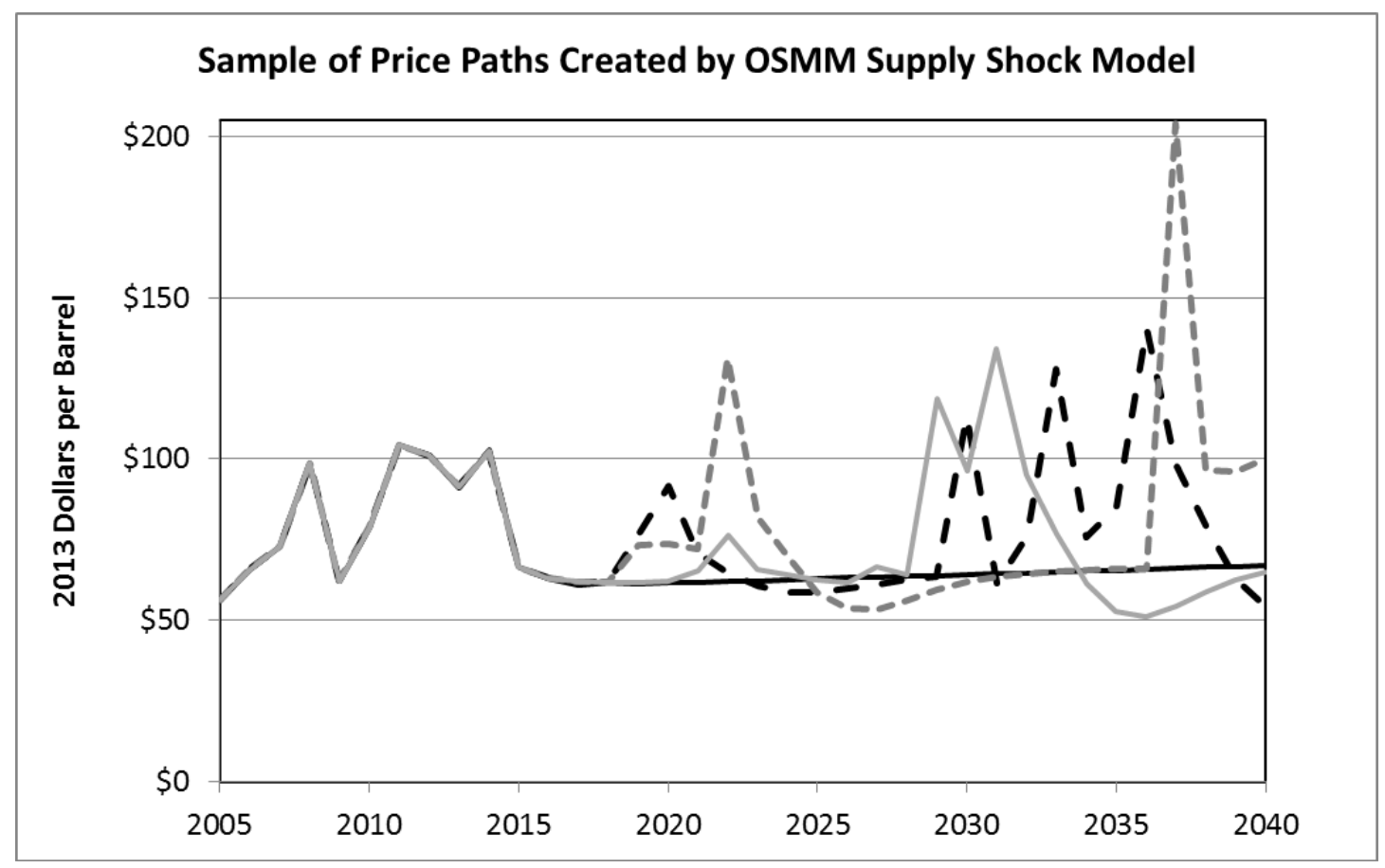


U.S. Oil Dependence: Is Energy Independence in Sight?

Energy Policy

David Greene and Changzheng Liu

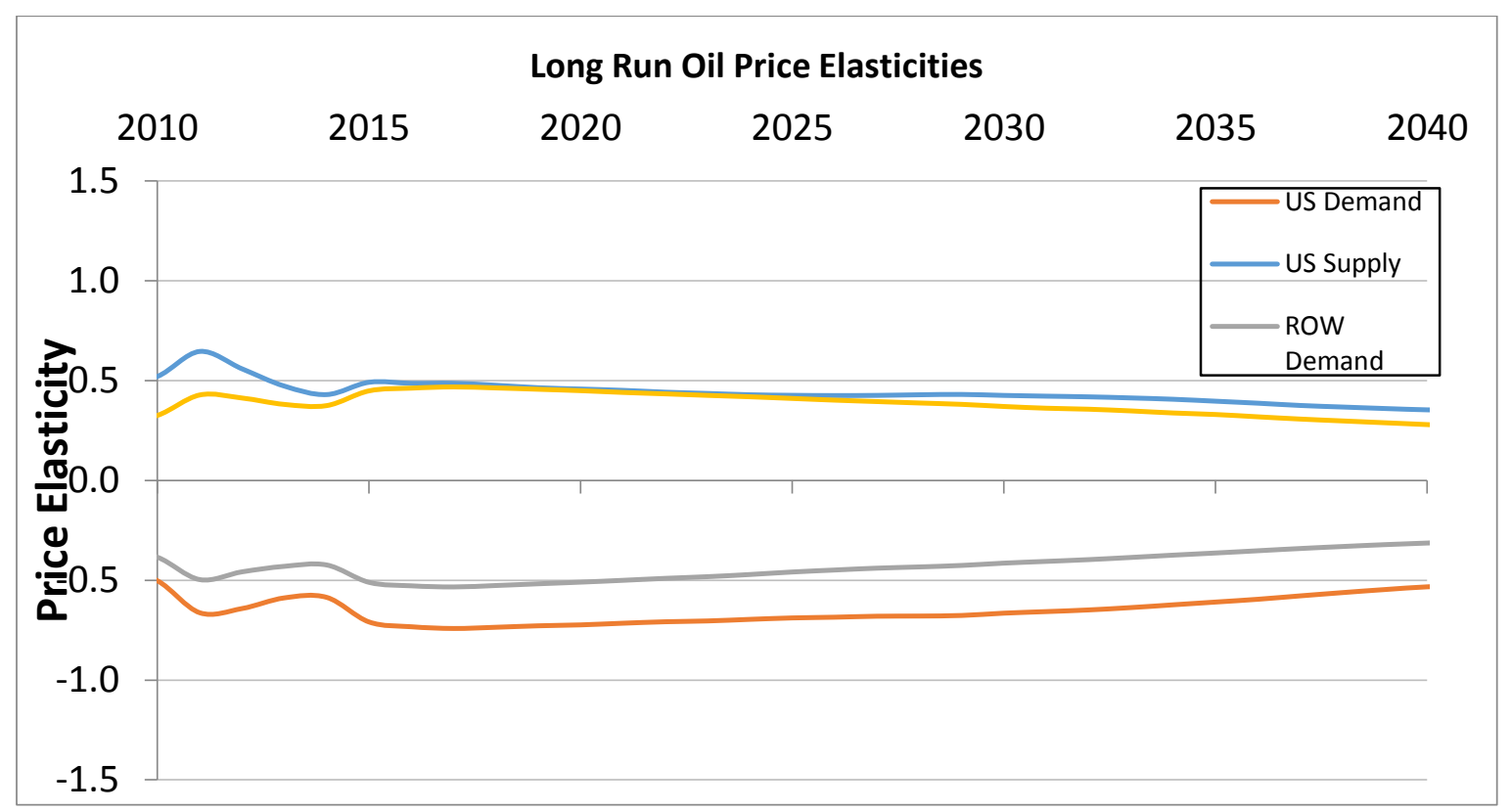




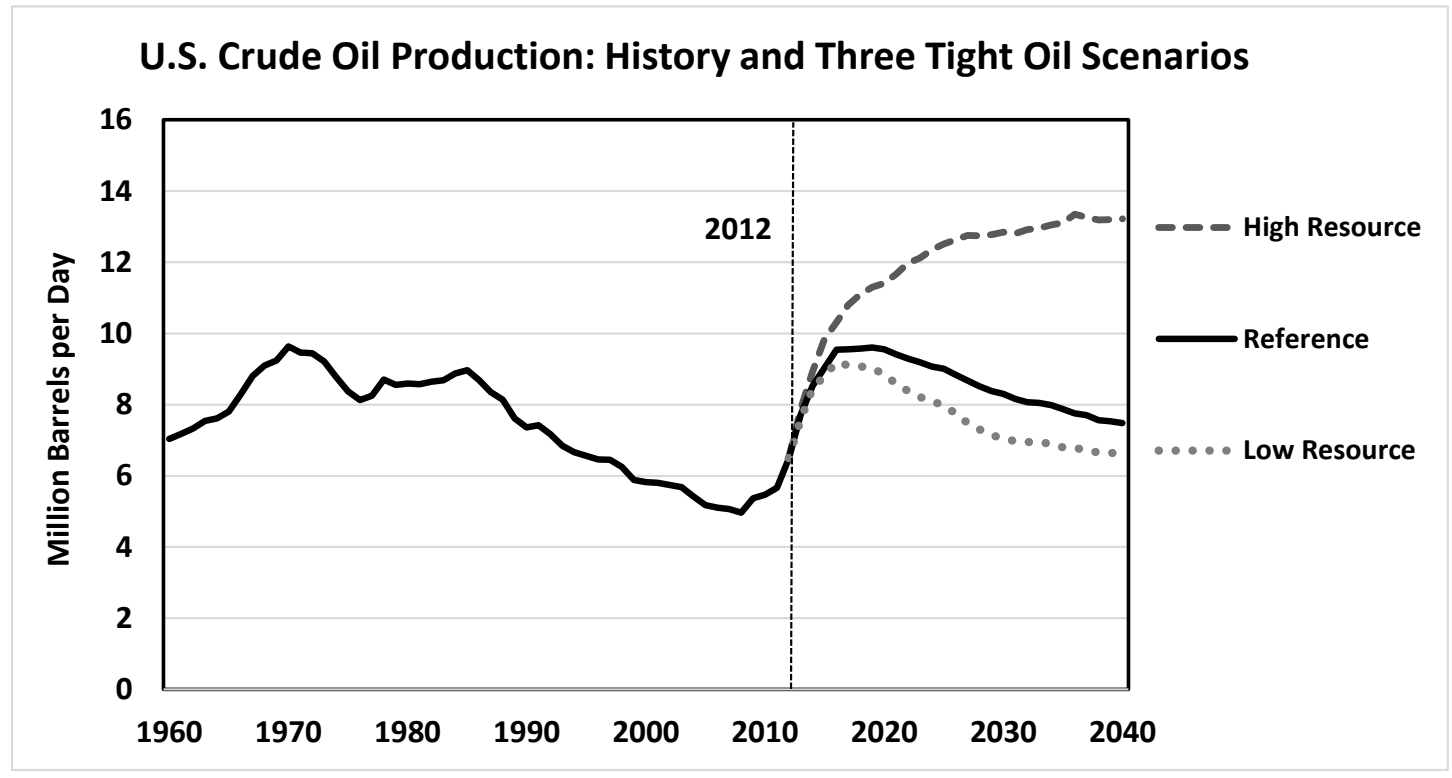


U.S. Oil Dependence: Is Energy Independence in Sight?

David Greene and Changzheng Liu

Energy Policy

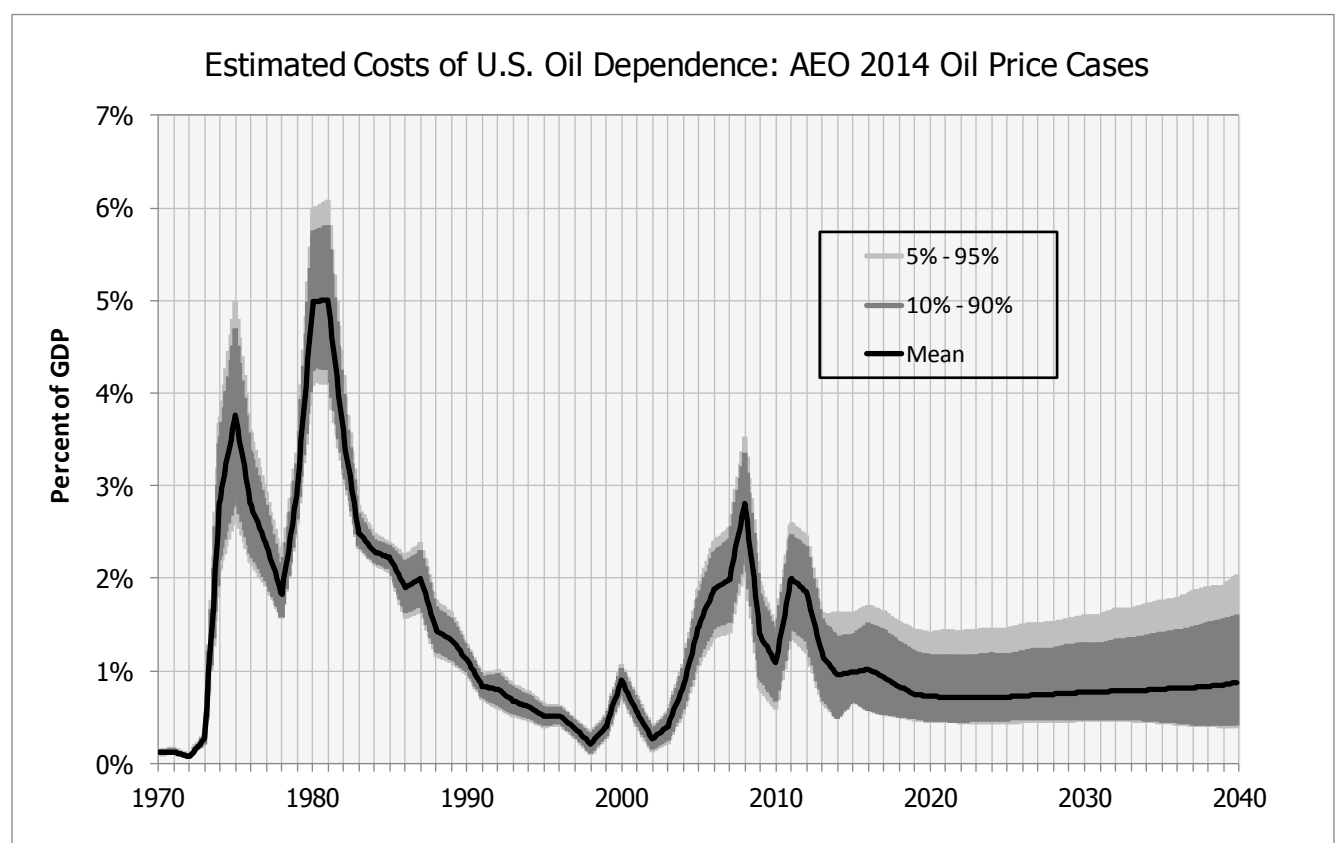


U.S. Oil Dependence: Is Energy Independence in Sight?

Energy Policy

David Greene and Changzheng Liu

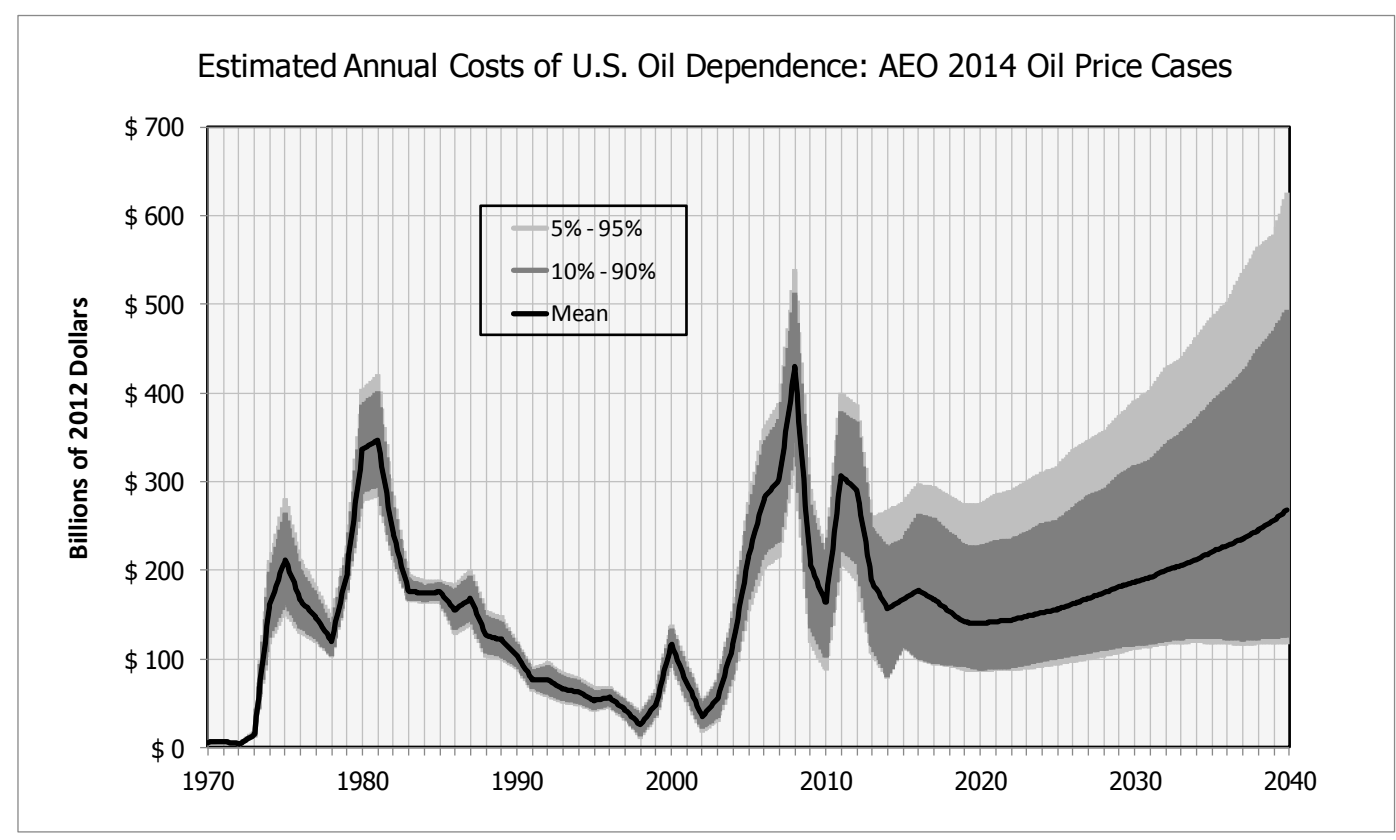


U.S. Oil Dependence: Is Energy Independence in Sight?

Energy Policy

David Greene and Changzheng Liu

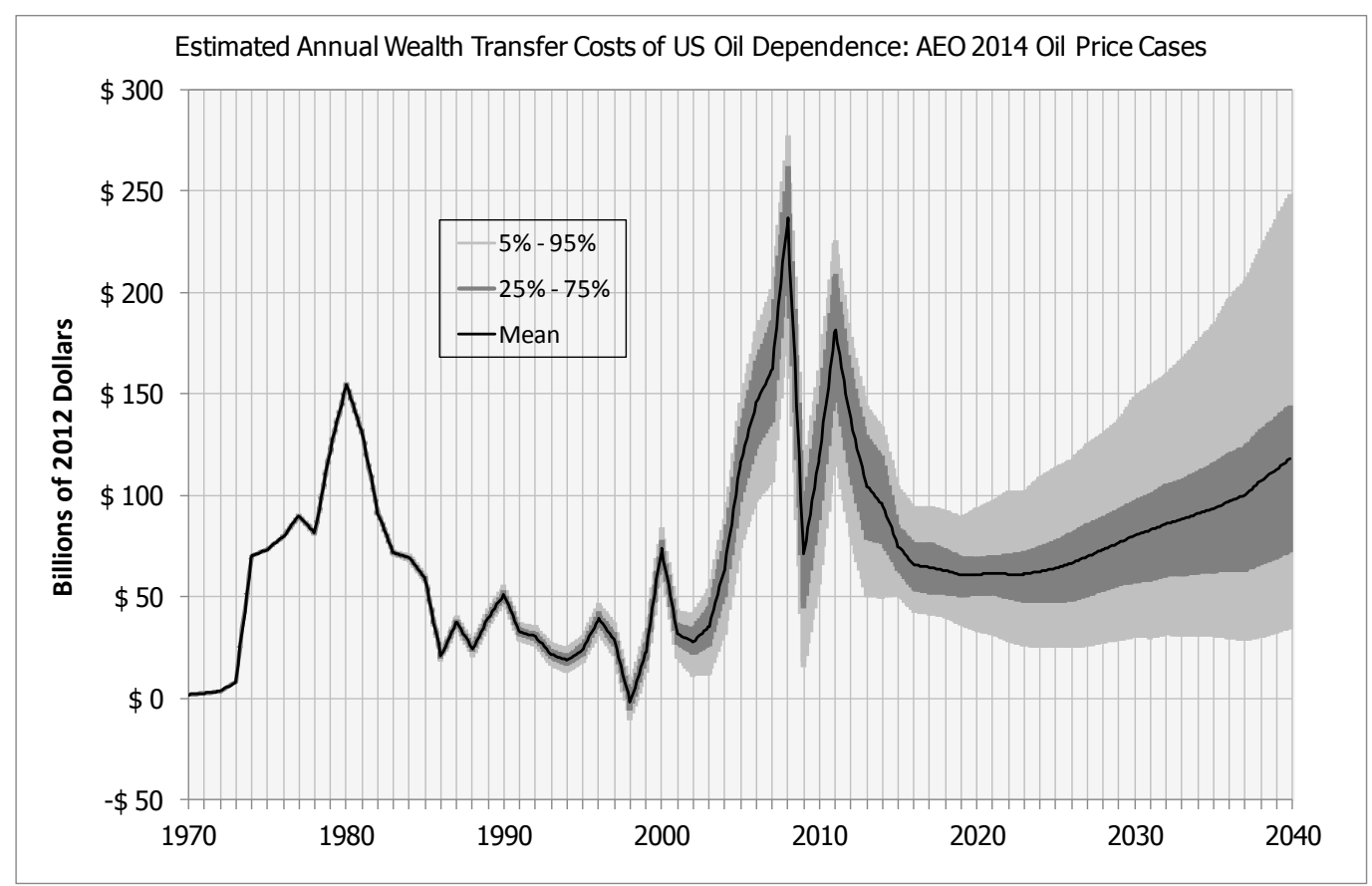


U.S. Oil Dependence: Is Energy Independence in Sight?

Energy Policy

David Greene and Changzheng Liu

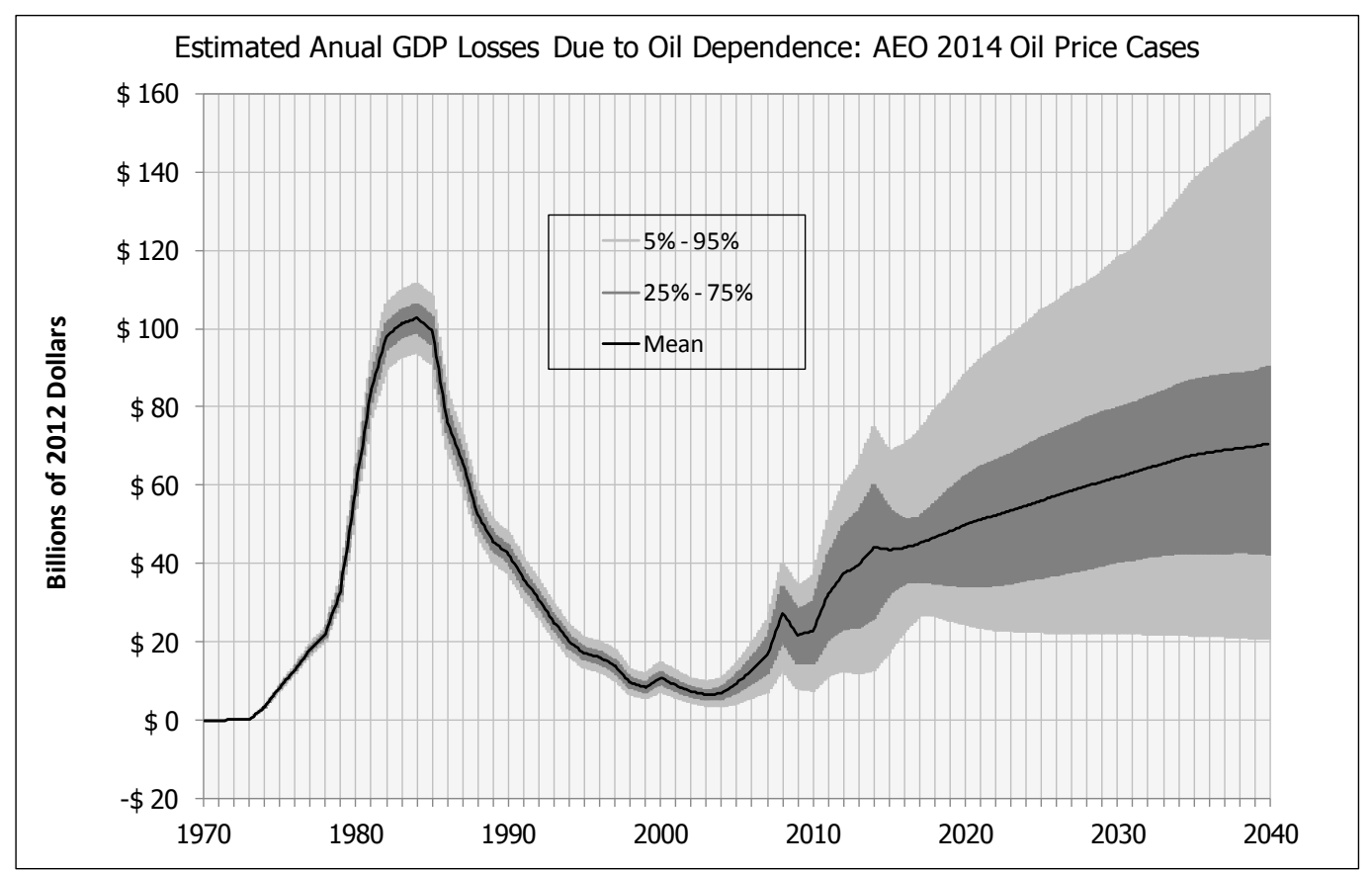


U.S. Oil Dependence: Is Energy Independence in Sight?

David Greene and Changzheng Liu

Energy Policy

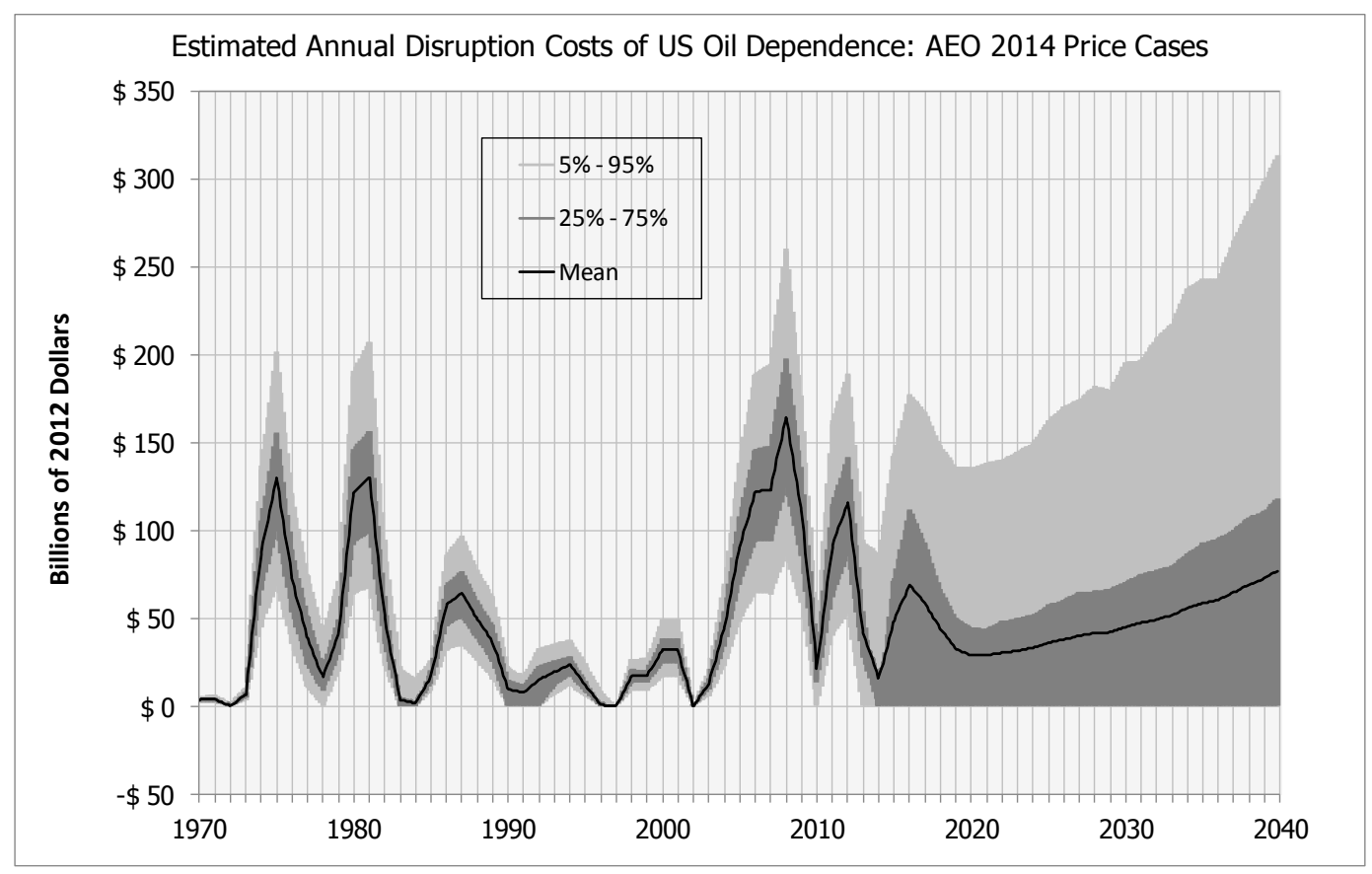


U.S. Oil Dependence: Is Energy Independence in Sight?

David Greene and Changzheng Liu

Energy Policy

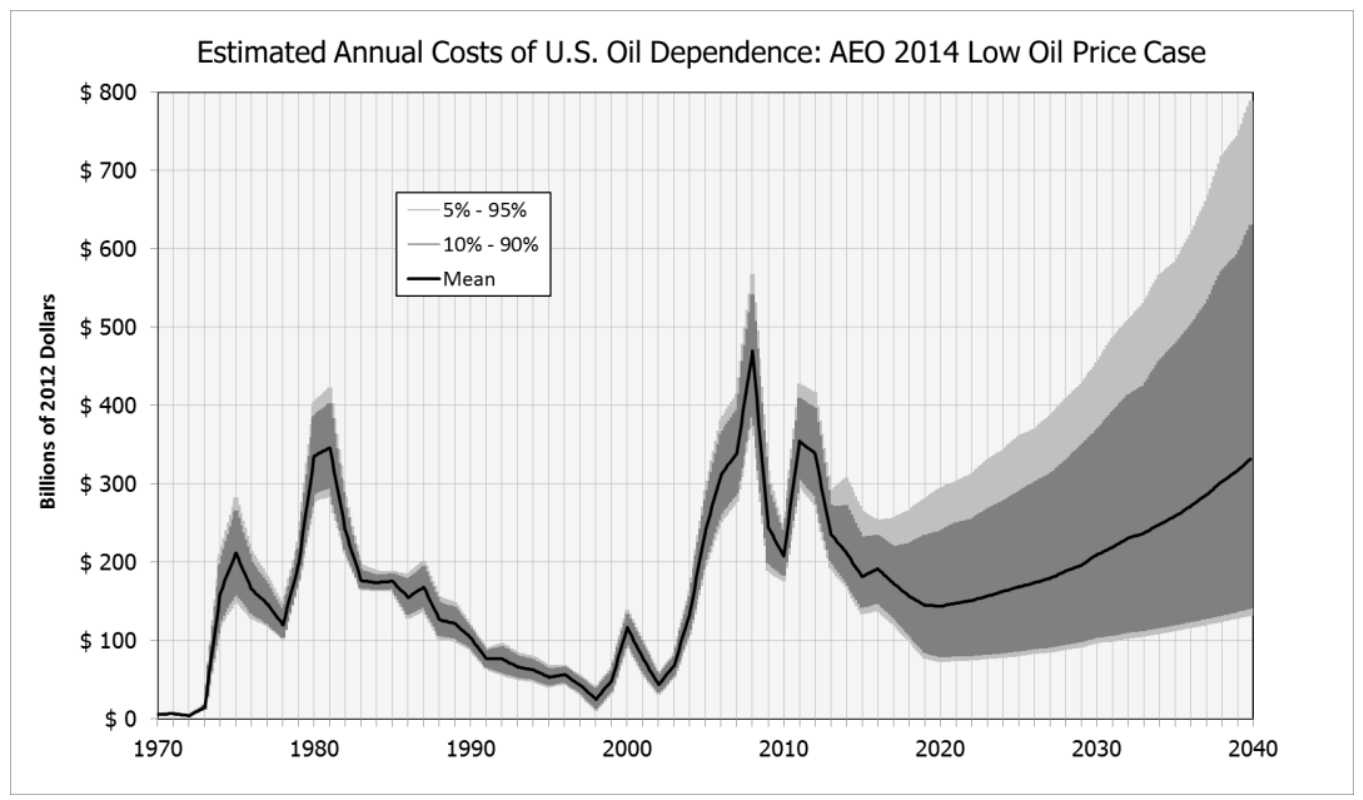


U.S. Oil Dependence: Is Energy Independence in Sight?

Energy Policy

David Greene and Changzheng Liu

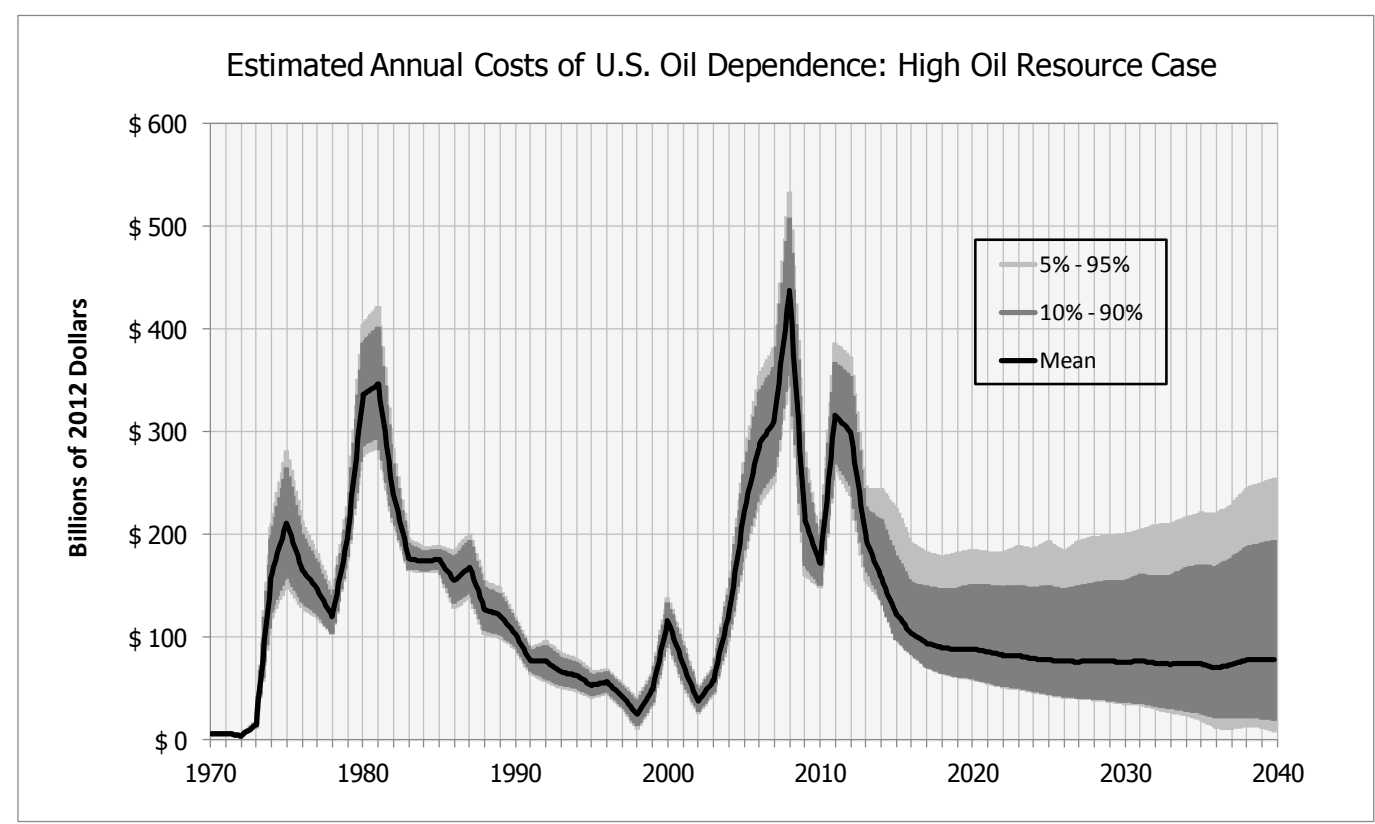


U.S. Oil Dependence: Is Energy Independence in Sight?

Energy Policy

David Greene and Changzheng Liu

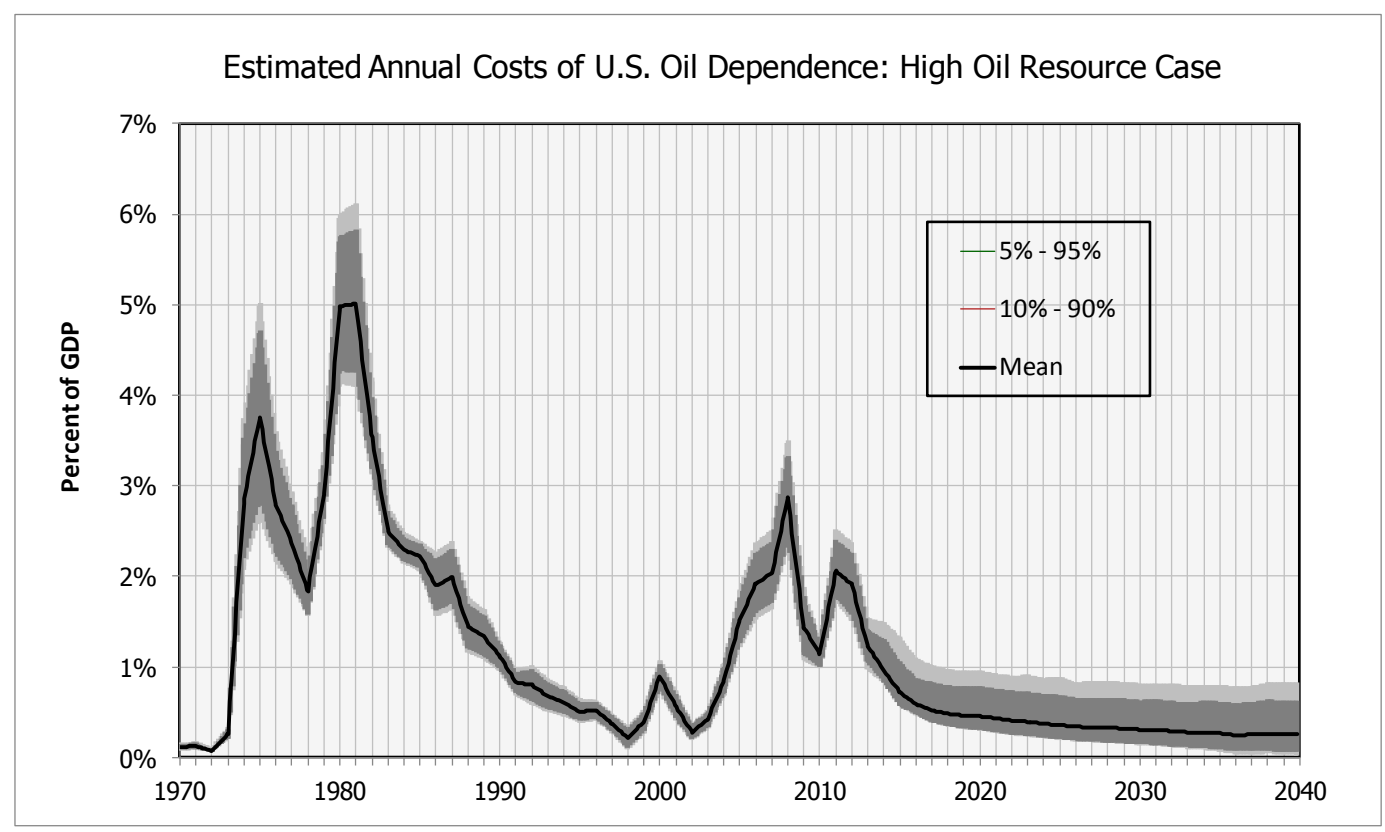




\section{TABLE 1 Probability Distributions for Parameters of the Monte Carlo Simulations}

\begin{tabular}{|c|c|c|c|c|c|}
\hline No. & Parameters & Distribution & Min & Mean & Max \\
\hline 1 & Oil Price Elasticity of GDP in 1983-86 & Triangular & -0.09 & -0.055 & -0.02 \\
\hline 2 & Disruption Costs Share of Elasticity & Triangular & -0.6 & 0.75 & 0.9 \\
\hline 3 & First Year Macro. Adj. Cost/Second Year Cost & Triangular & $1 / 3$ & 0.51 & $2 / 3$ \\
\hline 4 & Macroeconomic Costs Adjustment Rate & Triangular & 0.22 & 0.33 & 0.44 \\
\hline 5 & U.S. Oil Demand Elasticity & Triangular & -0.09 & -0.079 & -0.068 \\
\hline 6 & U.S. Oil Supply Elasticity & Triangular & 0.08 & 0.1025 & 0.125 \\
\hline 7 & Rest of World. Oil Demand Elasticity & Triangular & -0.09 & -0.079 & -0.068 \\
\hline 8 & Rest of World Oil Supply Elasticity & Triangular & 0.08 & 0.1025 & 0.125 \\
\hline
\end{tabular}

\section{U.S. oil dependence 2014: Is energy independence in sight? Highlights}

- Increased oil production and decreased use caused US oil imports to fall from $60 \%$ in 2005 to $27 \%$ in 2014.

- OPEC's market power appears to have increased due to lower oil price elasticities.

- Future costs of oil dependence to the US are likely to increase but decrease relative to GDP.

- If US oil resources are far larger than EIA estimates, the US could be oil independent by 2040 . 